\title{
Political decentralization and corruption: Evidence from around the world
}

How does political decentralization affect the frequency and costliness of bribe-extraction by corrupt officials? Previous empirical studies, using subjective indexes of perceived corruption and mostly fiscal indicators of decentralization, have suggested conflicting conclusions. In search of more precise findings, we combine and explore two new data sources - an original cross-national data set on particular types of decentralization and the results of a firm level survey conducted in 80 countries about firms' concrete experiences with bribery. In countries with a larger number of government or administrative tiers and (given local revenues) a larger number of local public employees, reported bribery was more frequent. When local—or central—governments received a larger share of GDP in revenue, bribery was less frequent. Overall, the results suggest the danger of uncoordinated rent-seeking as government structures become more complex.

\section{Simon Fan, Lingnan University, Hong Kong Chen Lin, Lingnan University, Hong Kong and Daniel Treisman, UCLA*}

September 2008

\footnotetext{
* Corresponding author: Professor Daniel Treisman, Department of Political Science, University of California, Los Angeles, 4289 Bunche Hall, Los Angeles, CA 90095-1472. Tel: 310.968.3274; Fax: 310.825.0778; email: treisman@polisci.ucla.edu. We thank Robin Boadway (the editor) and two anonymous referees for many constructive comments and suggestions that have helped improve the quality of the paper a lot.
} 


\section{Introduction}

How does political decentralization affect the frequency and the costliness of corrupt bribe-extraction by officials? Theories suggest conflicting conclusions. On one hand, by bringing officials "closer to the people” or encouraging competition among governments for mobile resources, decentralization might increase government accountability and discipline. On the other, decentralization could impede coordination and exacerbate incentives for officials at different levels to "overgraze" the common bribe base. More generally, one might expect a variety of effects associated with different types of decentralization to operate simultaneously, pulling in many directions, with different strength in different contexts.

A number of scholars have sought to answer this question empirically by looking for relationships between measures of political or fiscal decentralization and crossnational indexes of perceived corruption derived from surveys of risk analysts, businessmen and citizens. In particular, scholars have examined perceived corruption ratings produced by Transparency International (TI), the World Bank (WB), and the business consultancy Political Risk Services, which publishes the International Country Risk Guide (ICRG). The findings of these studies have been mixed and sometimes mutually contradictory.

Focusing on fiscal decentralization, Huther and Shah (1998), De Mello and Barenstein (2001), Fisman and Gatti (2002), and Arikan (2004) all report that a larger subnational share of public expenditures (as measured in the IMF’s Government Finance Statistics) was associated with lower perceived corruption using the TI, ICRG, or WB indexes. Enikolopov and Zhuravskaya (2007) do not report an unconditional effect, but find that a larger subnational revenue share is associated with lower perceived corruption (using WB, but not TI, data) in developing countries with older political parties (and vice versa); a larger subnational revenue share in developing countries where there are few parties in government is associated with lower corruption (on both WB and TI measures) (and vice versa). Looking at political rather than fiscal indicators, Goldsmith (1999), Treisman (2000), and Kunicová and Rose Ackerman (2005) all found that federal structure was associated with higher perceived corruption. 
However, in a more recent review of the empirical literature, Treisman (2007) suggested that neither the (negative) expenditure decentralization effect nor the (positive) federalism effect was robust. The fiscal decentralization effect was weakened by controlling for national religious traditions, and the federal effect disappeared as the number of countries in the sample increased. Treisman (2002) and Arikan (2004) explored whether smaller local units were associated with less corruption because of more intense interjurisdictional competition, but obtained inconclusive results. Finally, examining the effect of the vertical structure of states, Treisman (2002) found that a larger number of administrative or governmental tiers correlated with higher perceived corruption, but whether subnational governments were appointed or elected did not have a clear effect.

In this paper, we advance and improve upon this literature in three ways. First, our analysis exploits an original cross-national data set on different varieties of decentralization, compiled from more than 480 sources. This allows us to design indicators of particular types of decentralization to match the underlying logic of specific arguments. We look for relationships between reported experience with corruption and: (i) the number of tiers of government or administration in the country (see Section 3.1), (ii) the average land area of lowest tier units (see Section 3.2), (iii) several proxies for the extent of subnational political decisionmaking (see Section 3.2 and others), (iv) an indicator for whether lower tier units have elected executives (see Section 3.3), (v) a measure of subnational tax revenues as a share of GDP (see Section 3.4), and (vi) an estimate of the share of subnational government personnel in total civilian government personnel (see Section 3.5).

Second, most previous studies have used perceived corruption indexes that rely on the aggregated perceptions of businessmen or country experts, many of whom may have formed impressions—perhaps subconsciously—based on common press depictions of countries or conventional notions about what institutions or cultures are conducive to corruption. More recently, a second type of data has become available: survey responses of businessmen and citizens in particular countries about their own (or close associates') concrete experiences with corrupt officials. In a recent study, Treisman (2007) showed that, for developing countries, the perceived corruption indexes were relatively weakly correlated with 
experience-based indicators. Among countries rated as highly corrupt on the subjective indexes of TI, $\mathrm{WB}$, and the ICRG, there is great variation in the level of reported experience with corruption. For instance, on the World Bank perceived corruption index, Argentina and Macedonia were both rated about equally corrupt in 2000: they were ranked 103 and 114 respectively out of 185 countries. But respondents from these two countries gave dramatically different answers when surveyed by the United Nations Interregional Crime and Justice Research Institute (UNICRI) in the late 1990s about their own personal experience with bribery. When asked whether during the previous year "any government official, for instance a customs officer, police officer or inspector” had asked or expected them to pay a bribe for his services, respondents in Argentina were three and a half times as likely as the Macedonian respondents to say yes. While Argentina had the second highest frequency of reported demands for bribes (second only to Indonesia), Macedonia was only $24^{\text {th }}$ in the list of 49 countries, about even with South Africa and the Czech Republic. Perhaps of greater concern, a number of factors commonly believed to affect corruption (democracy, press freedom, oil rents, even the percentage of women in government) do an excellent job explaining the cross-national varietion in the subjective corruption indexes (R-squareds approaching .90). But the same factors are mostly uncorrelated with the frequency or scale of self-reported experiences with corruption once one controls for income. One cannot help wondering if the businessmen and experts whose perceptions are being tapped might be inferring corruption levels from its hypothesized causes.

In this study, we explore the results of an experience-based survey of business managers conducted in 80 countries. The World Business Environment Survey interviewed managers from more than 9,000 firms in 1999-2000. We focus on two questions. Respondents were asked: "Is it common for firms in your line of business to have to pay some irregular 'additional payments' to get things done?” and “On average, what percent of total annual sales do firms like yours typically pay in unofficial payments/gifts to public officials?” The first question provides an indicator of the frequency of bribery, while the second aims to estimate its scale. The relationship between the proportion of respondents that said irregular payments were expected “always”, “mostly”, or “frequently”, and the World Bank’s subjective index of perceived corruption for the year 2000 are graphed in Figure 1. It is interesting to note that while 
businessmen in France and Brazil gave very similar responses to this question (about 27 percent saying bribes were expected "always”, “mostly”, or “frequently”), France is rated as among the least corrupt countries on the World Bank’s index, while Brazil is perceived to have much higher corruption. Of course, no approach is completely without problems; it is possible that questions that focus more closely on managers' direct experience with corruption might not be answered with complete frankness for fear of some kind of self-incrimination. However, we believe this danger is less serious than the danger that bias will creep into the assessments of "experts” and foreign businessmen because of inconsistencies in media coverage. (As a robustness check, we compare our results to those obtained using the traditional perceived corruption data.)

[Figure 1 here]

Third, besides permitting us to focus on experience-based rather than subjective indicators of corruption, the WBES makes it possible to control better for individual characteristics of survey respondents (which vary systematically across countries). Specifically, we can control for the size, ownership structure, investment level, and level of exports of firms in analyzing their managers' responses on corruption.

In the next section, we briefly introduce the decentralization data used in the paper. We review common arguments about the consequences of decentralization for governance in section 3 , and in section 4 discuss the corruption data and controls. We then look for evidence of the hypothesized effects in the WBES. In Section 5 we present empirical results and discuss robustness tests. Section 6 discusses the findings and concludes.

\section{A new data set on governance in multi-level states}

Previous work has often used measures of fiscal decentralization or simple dummies for federal structure to proxy for various other types or dimensions of political and administrative decentralization. The data set introduced here permits a more fine-grained analysis. It contains measures of various characteristics of multi-level states as of the mid-1990s, based on information from more than 480 sources. $^{1}$

\footnotetext{
1 These data and the full list of sources will be made available on the corresponding author's web site.
} 
A first dimension is simply the number of tiers of government or administration. Our data set contains information on this for 156 countries. We coded a level of administration as a "tier" if there existed a state executive body at that level which met three conditions: (1) it was funded from the public budget, (2) it had authority to administer a range of public services, and (3) it had a territorial jurisdiction. This definition includes both bodies with decisionmaking autonomy and those that are essentially administrative agents of higher level governments. On this measure, Singapore as of the mid-1990s had just one tier, while Uganda had six.

Multi-level states differ also in the number and size of their lowest-tier units. This is relevant, for instance, to arguments about interjurisdictional mobility. The data set contains estimates of the number of bottom level units (BOTTOM UNITS), and the “average” area of these (BOTTOM SIZE), calculated by simply dividing the country's area by the number of units. ${ }^{2}$ While Guyana in the mid-1990s had just six incorporated towns, India had some 235,000 lower tier village governments. The average area of the lowest tier units ranged from 2.2 square kilometers in Bangladesh to 83 square kilometers in Botswana.

Perhaps most important, multi-level governments differ in how authority is divided among the various tiers. Measuring the degree of decisionmaking autonomy of local governments in a systematic way is notoriously difficult. Our data set contains a simple dummy (AUTONOMY), which records for 133 countries whether the constitution assigned at least one policy area exclusively to subnational governments or gave subnational governments exclusive authority to legislate on matters not constitutionally assigned to any level. This variable is less than ideal. For one thing, informal behavior often diverges from what is written in the constitution. In some countries—Azerbaijan and Uzbekistan, for instance—it seems unlikely the constitutional provisions are scrupulously observed. ${ }^{3}$ Yet determining the degree of actual decisionmaking decentralization in any country is inescapably subjective. Experts often disagree with regard to a single country, let alone agreeing on crossnational comparisons. At the same time, the number and relative

\footnotetext{
2 A better variable would be the average area of all actual units, but data were not available. Since the number of bottom-tier units changes over time as units split or combine, the variable is only a rough indicator.

${ }^{3}$ Both inherited Soviet-era internal “autonomous republics”, whose rights are constitutionally protected.
} 
importance of policy areas constitutionally assigned to subnational governments differs, and there is no obvious way to add these up. AUTONOMY also focuses mostly on intermediate levels—states, provinces, or regions - whereas the governments most relevant to questions of interregional competition will often be at the local level. We supplement the use of AUTONOMY in our analysis with several other indicators of decisionmaking decentralization available from other data sets and sources. ${ }^{4}$

To capture differences in the extent of local electoral accountability, we constructed two variables. The first (BOTTOM TIER ELECTION) focuses on the mode of selection of the chief executive of the bottom tier government, while the second (SECOND LOWEST TIER ELECTION) focuses on the executive at the next highest tier. Each of these takes the value 1 if the executives at the relevant tier were (as of the mid-1990s) directly elected or chosen by a directly elected local assembly, and 0 if the executives were appointed by higher level officials. They take the value 0.5 if some chief executives were appointed while others were elected.

Details of the variables and the correlations between them and some other common decentralization indicators are shown in Tables 1 and 2. While we focus on the impact of political decentralization on corruption in this study, the political decentralization measures introduced here could be used to examine the effects of decentralization on various other aspects of government performance such as service quality, provision of public goods, and tax collection.

[Tables 1 and 2 here]

\section{Decentralization and corruption: theory}

Political or fiscal decentralization might affect the quality of government in various ways. We discuss

${ }^{4}$ Our definition of AUTONOMY is close to various classic definitions of federalism. Riker (1964) defines states as "federal" if: (1) they have (at least) two levels of government, and (2) each level has "at least one area of action in which it is autonomous." The latter requirement must be formally guaranteed, for instance in a constitution (Riker 1964, p.11). This is close to Robert Dahl's definition of federalism as "a system in which some matters are exclusively within the competence of certain local units - cantons, states, provinces-and are constitutionally beyond the scope of the authority of the national government; and where certain other matters are constitutionally outside the scope of the authority of the smaller units” (Dahl 1986, quoted in Stepan 2001, p.318; italics in original). In our operationalization, AUTONOMY is a broader category because we assign a " 1 " also to countries that devolve decisionmaking rights to certain selected regions but not to others. 
here a number of arguments made in previous work, specifying to which type of decentralization each applies. We do not expect most to be fully general, and some could operate simultaneously or offset each other in complicated ways.

\subsection{Vertical competition}

Governments can use the power to regulate to extract bribes from firms or citizens. If the bribe rate is set too high, this will discourage firms or citizens from producing wealth, reducing the amount of revenue actually extracted. Thus, a unitary predatory government will moderate its demands. However, if multiple officials regulate the same actors and fail to coordinate, they may set the total bribe rate higher than would be optimal for a unitary, bribe-maximizing government (Shleifer and Vishny 1993). Indeed, the aggregate bribe burden is likely to increase with the number of independent regulators. If officials at each tier in a multi-level state can regulate, the burden of bribery should increase with the number of tiers. The logic is that of "double marginalization” under vertical integration (Spengler 1950) or “overgrazing” in taxation (Keen and Kotsogiannis 2002, Berkowitz and Li 2000). ${ }^{5}$

Although appealing, this argument might fail for various reasons. The number of independent regulators might not increase with the number of tiers. In fact, administrative complexity at the center and decentralization might be substitutes— to govern directly, a central government may need to create more agencies in the capital to take the place of local field agents. Moreover, career concerns might motivate local officials in a decentralized state to behave honestly. The hope of rising to higher office may cause local officials to cultivate a reputation for integrity (Myerson 2006). Finally, if elected governments at different levels provide comparable public goods, some scholars suggest they may be disciplined by yardstick competition. Voters can use the performance of each as a benchmark to judge the efficiency of the other (Salmon 1987, Breton 1996, p.189). If one government over-regulates in order to extract bribes, its

\footnotetext{
${ }^{5}$ In a notable recent contribution, Olken and Barron (2007) find evidence consistent with double-marginalization using Indonesian data.
} 
performance will look bad in comparison to its more liberal counterparts at other levels. To test this argument, we use the variable TIERS, measuring the number of levels of government or administration.

\subsection{Interregional competition}

If capital or labor is mobile and local governments choose policies, they may tailor these to attract the mobile factor (Hayek 1939, Tiebout 1956). Officials who steal or waste resources will lose residents and businesses to other regions, reducing their tax base. If they over-regulate in order to extract bribes, firms will flee to lower-regulation settings. In this way, interjurisdictional competition may discipline local governments, reducing corruption and causing them to supply public goods efficiently (Brennan and Buchanan 1980; Montinola et al. 1995). The impact of such competition should be greater, the lower the cost of moving between units; moving costs should increase with the size of the units.

However, the fear of losing mobile capital may fail to discipline local governments for a number of reasons (e.g., Cai and Treisman 2005). Or governments may compete to attract capital by promising corrupt benefits to local businesses at the expense of the central government (Cai and Treisman 2004). Even if interjurisdictional competition motivates local politicians to reduce corruption, it does not increase their capacity to do so. If most bribes are taken by local bureaucrats and anti-corruption measures must be implemented by the same bureaucrats, it may matter little how motivated the politicians are to clean up government. And if anti-corruption measures are costly, the inability to tax mobile capital may make it harder for local governments to fund such efforts.

The relevant type of decentralization here is devolution of decisionmaking about regulation or taxation to subnational levels; among countries with a similar level of such devolution, one might expect a positive correlation between average size of the subnational units and corruption. To measure devolution of decisionmaking, we start with the variable AUTONOMY. But we supplement it with various alternatives. First, we created a dummy for whether the country was classified as "federal” by a leading expert on federalism as of the mid-1990s (FEDERAL) (Elazar 1995). Second, in an attempt at a more fine-grained 
analysis, we tried using measures of the extent of decisionmaking decentralization in specific public service areas, constructed by Henderson (2000). Henderson coded whether, in 49 countries in 1960-95, authority for primary education, local highway construction, and local policing belonged to the central, regional, or local governments, or some combination of the three. ${ }^{6}$ (Of these 49 countries, 35 were included in the WBES.) Both local road construction and local policing could impinge on the operations of almost any business, but it is harder to see how the regulation of primary schooling could lend itself to widespread extraction of bribes from businesses, so we focused on the former two indicators. We constructed two variables (ROADS LOCAL and POLICE LOCAL) which took the value 1 if, as of 1995, the local governments participated in decisionmaking on the issue in question, and 0 otherwise. $^{7}$ The arguments in Section 3.2 suggest that when ROADS LOCAL and/or POLICE LOCAL equal one, greater factor mobility might be associated with lower corruption. To capture the average size of subnational units, which should be positively related to moving costs, we used our variable BOTTOM SIZE.

\subsection{Electoral accountability}

For several reasons, holding elections at the local level rather than just the center might increase the accountability of government (see e.g. Seabright 1996). First, voters might have better information about local than about central government performance. Second, whereas national elections focus on government performance nationwide, local elections can focus more specifically on performance in each region. Third, dividing up responsibilities among several levels of elected government might make it easier for voters to attribute credit or blame among them (under decentralization, one can vote for an honest central government

\footnotetext{
6 The details of the data set constructed by Henderson (2000) can be obtained through direct communications with Henderson.

7 In only one case-local highway construction in Uganda-did the local governments enjoy exclusive authority. We also constructed an indicator (SHARED RESPONSIBILITY) for the number of government levels participating in decisionmaking in these two policy areas (the more governments involved, the greater the potential for predatory extraction and "overgrazing”). Values ranged from 2 if for both local highways and policing only one level could make policy (as in Syria or Egypt), to 6 if, for both areas, all three levels of government could participate (as in the US). From the arguments in Section 3.1, one might expect SHARED RESPONSIBILITY to correlate positively with corruption. In fact, it was never significant, so we do not show results including it.
} 
and against a corrupt local government rather than having to vote for or against the team as a whole). ${ }^{8}$ Fourth, the smaller a unit's electorate, the easier it should be for voters to coordinate on a voting strategy to discipline the incumbent.

Questions can be raised about each of these arguments. First, local corruption can be concealed at least as well as central corruption, and watchdog groups and investigative journalists tend to devote more resources to monitoring national government since the stakes are generally higher. Second, voters evaluate incumbents on multiple dimensions and it is not clear whether corruption will be more salient in local or in national elections. Even if voters voted on just the corruption question, competition in a national election should often motivate central candidates to fight corruption in each district (if they do not, their adversary will, winning votes in the affected unit). Third, dividing responsibilities among levels may muddle rather than clarify the attribution of responsibility (compare a system in which two levels share responsibility for all policy areas to one in which a central government is alone responsible for all). Finally, coordinating is only significantly easier in groups that are very small (and smaller than the electorates of most existing local districts). Even in tiny villages, there are many dimensions on which voters could judge local officials, rendering coordination to discipline them on corruption problematic. ${ }^{9}$ To capture differences in the extent of local electoral accountability, we used the variables BOTTOM TIER ELECTION and SECOND LOWEST TIER ELECTION.

\subsection{Fiscal incentives}

The greater is corruption, the lower will be the motivation of firms to produce. Given this, some argue that corruption will fall if local officials are given a large personal stake in local economic activity. Under tax-sharing systems, the larger the share local governments retain of marginal tax revenues, the lower

\footnotetext{
${ }^{8}$ Besley and Coate (2003) make a similar argument about why direct election of regulators—rather than their appointment by elected officials - might lead to greater responsiveness to voters by reducing the number of issues on which each vote is cast.

${ }^{9}$ Electoral decentralization also eliminates accountability of local officials to voters outside their unit, which might itself increase some kinds of corruption. A locally elected sheriff could increase his town's revenues, taking a cut for himself, by inaccurately citing out-of-town motorists for speeding.
} 
should be their incentive to extract bribes (Montinola, Qian, and Weingast 1995, Zhuravskaya 2000, Jin et al. 2005). Since the argument relates to the marginal rate at which local governments benefit from increased local business activity, the relevant variable is the local governments' revenue as a share of local income at the margin. As usual, there are caveats. Increasing local governments' share means decreasing the shares of other levels. If local governments become more motivated to support economic performance, governments at other levels should become less motivated. Since, for better or worse, governments at all levels influence economic performance, the resulting net effect is indeterminate (Treisman 2006). Moreover, local officials may derive greater utility from bribe revenue, which they can spend at will, than from increased revenue officially received by the local budget, which may be costly to embezzle. If officials are already constrained by the risk of detection from embezzling more, then increasing the local tax share may not make them want to reduce their bribe taking in order to expand the local budget.

To test this argument, we use subnational government revenues as a percentage of GDP. The data are mostly from the IMF’s Government Finance Statistics Yearbooks (as collected in the World Bank's database of fiscal decentralization indicators), supplemented by additional sources on specific countries. We took the average value for all available years between 1994 and 2000. There are some missing observations in this variable so the sample size falls from 67 countries (6,676 observations) to 54 countries (5,598 observations) when we include it. Some previous studies used a variable measuring the share of local revenues or expenditures in total public revenues or expenditures to look for the effects of fiscal decentralization. However, since the argument here concerns the share of local income that local governments retain through taxation, we prefer an indicator that measures this more closely-the share of local revenues in GDP.

A better variable would have been the marginal revenue rate for local governments from locally generated income; however, cross-national data on marginal rates were not available, so we had to use the average rate instead. We control in these regressions for total government revenues as a share of GDP, since larger government might be associated with both greater corruption and higher local taxation. 


\subsection{Local collusion}

Some economists suggest local officials are simply more susceptible to corruption than their central counterparts, perhaps because they have more opportunities for face-to-face interactions with businessmen (e.g., Prud'homme 1995, Tanzi 1995, Bardhan and Mookherjee 2000) Local press and citizen groups may be weaker — and more subject to intimidation or cooptation— than at the center. Interest groups may be more cohesive at the local level, leading to greater state capture. By this logic, government should be more corrupt, the greater the share of government personnel located at subnational levels.

However, one could also argue the opposite. Even if the intimacy of interaction and the cohesiveness of interest groups are greater at the local level, the potential kickbacks and payoffs in national politics are likely to be higher. As noted in Section 3.3, voters are often assumed to be better informed about their local governments than about politics in the nation's capital. In any case, the real question is not whether local governments are likely to be more corrupt than central governments but whether elected local governments with decisionmaking power are likely to be more or less corrupt than centrally appointed local agents with more restricted authority. Whether there is a general answer to this question is unclear. To test this argument, we constructed a measure of government personnel decentralization- the subnational share in total civilian government employees as of the mid-1990s, as estimated by Schiavo-Campo et al. (1997). We control for total government employment as a share of the labor force, since, as noted, the size of government as a whole might itself be related to corruption.

\section{Corruption data and controls}

\subsection{The survey}

The WBES was conducted in 1999 and 2000 by a team from the World Bank. Managers from over 9,000 firms in more than 80 countries were surveyed with a standard questionnaire. ${ }^{10}$ The main purpose was to identify the driving factors behind and obstacles to enterprises’ performance and growth around the world.

${ }^{10}$ For more information on the survey, see http://www.ifc.org/ifcext/economics.nsf/Content/ic-wbes. 
The questionnaire touched on many aspects of firms’ operations, including corruption, regulation, and the institutional environment. The firms surveyed varied in size (including a large number of small and medium-size enterprises), ownership (both public and private), industrial sector, and organizational structure. Because of missing firm-level and decentralization variables, the number of firms we could include in our analysis starts at about 6,700 (from 67 countries), and falls lower as additional variables are added. Previous work has used the WBES data to study such outcomes as firm growth, investment flows, the effects of institutions, property rights, and corruption (Hellman, Kaufman, and Schankerman, 2000; Djankov, La Porta, Lopez-De-Silanes, and Shleifer, 2003; Beck, Demirguc-Kunt and Maksimovic, 2005; Acemoglu and Johnson, 2005; Beck, Demirguc-Kunt and Levine 2006; Ayyagari, Demirguc-Kunt and Maksimovic, 2007, Barth, Lin, Lin and Song, 2008). According to Reinikka and Svensson (2006, p.367), the WBES shows that "with appropriate survey methods and interview techniques, it is possible to collect quantitative data on corruption at the micro-level.”

\subsection{Measures of corruption}

We constructed two measures of corruption using WBES data. The first, which we call BRIBE FREQUENCY, is based on a question in which respondents were asked: "Is it common for firms in your line of business to have to pay some irregular 'additional payments' to get things done.” The interviewers assured respondents that their responses would be kept completely confidential, and that their names and the names of their firms would never be identified in any publication or survey document. In addition, to encourage honest responses, the question asked only about unofficial payments "in your line of business" rather than those "paid by your firm” (Johnson, McMillan and Woodruff 2002). Managers could choose between six responses: 1 (never), 2 (seldom), 3 (sometimes), 4 (frequently), 5 (usually), and 6 (always). Thus, the variable BRIBE FREQUENCY takes these six values; a larger value represents more frequent bribery payments. ${ }^{11}$ Overall, about 69 percent of respondents $(6,300$ out of 9,130) reported that firms like theirs paid bribes to public officials to get things done. About 15 percent of the firms reported that this

11 The original survey offered the six choices in reverse order: (1) always, (2) mostly, (3) frequently, (4) sometimes, (5) seldom, (6) never. We recoded the variable to make the empirical results more intuitive. 
occurred “4 ( frequently),” 12 percent reported “5 (usually),” and 9 percent reported “6 (always)”. In countries such as Bangladesh, Nigeria, Tanzania, Thailand, Uganda, and Zimbabwe, more than 90 percent of the firms sampled reported that such unofficial payments occurred at least occasionally. The lowest rate of reported bribery was in Singapore, where 90 percent said firms like theirs never had to make unofficial payments.

Our second measure, which we call BRIBE AMOUNT, was constructed from a question that asked: “On average, what percent of total annual sales do firms like yours typically pay in unofficial payments/gifts to public officials?” The survey offered seven choices: (1) 0 percent, (2) 0-1 percent, (3) 1-1.99 percent, (4) 2-9.99 percent, (5) 10-12 percent, (6) 13-25 percent, and (7) over 25 percent. Out of the original sample of 80 countries, respondents in 60 countries answered this question. Overall, more than 62 percent of those who responded reported that firms like theirs typically made positive unofficial payments to public officials. More than 38 percent reported that such payments were greater than 1 percent of total sales; about 11 percent said payments exceeded 10 percent of total sales. The average size of such payments varied across both countries and the firms within them.

The two measures of corruption are complementary, capturing different dimensions that may not always coincide (bribes could be frequent but tiny, or rare but large). In some respects, the amount of bribes paid is the more interesting variable. However, it was also apparently perceived by respondents as more sensitive: in one quarter of the countries, respondents did not answer this question. By contrast, the response rate for the first question was high: the only country in which none answered the question was China, and the response rate ranged from 63 percent in Senegal to 100 percent in the Philippines and Thailand, with an average of 92 percent. ${ }^{12}$ Consequently, our regressions of BRIBE FREQUENCY can include a larger range of countries than those for BRIBE AMOUNT. As will become clear, our results using the two variables are very similar and complementary.

\footnotetext{
${ }^{12}$ In order to further explore the potential issue of non-randomly missing responses, we created a truncated sample from which all the firms that were missing observations on any of the following key variables were excluded: corruption frequency, firm size, government ownership, foreign ownership and exporting status. We then compared the truncated sample to the full sample for the same firm characteristics. (Since many were missing data on just one of these, the full sample could differ substantially from the truncated sample.) In all cases, the differences between the truncated sample and full sample were not statistically significant. We also tried dropping some countries with relatively high missing response rates (e.g. Senegal) from the sample and found the empirical results highly robust.
} 
The WBES also asked respondents about the particular contexts in which bribes were demanded. Specifically, it asked whether "firms like yours typically need to make extra, unofficial payments to public officials for any of the following purposes...” and listed six possibilities: "to get connected to public services (electricity, telephone), to get licenses and permits, to deal with taxes and tax collection, to gain government contracts, when dealing with customs/imports, and when dealing with courts”. For each of these, respondents could choose from six answers: 1 (never), 2 (seldom), 3 (sometimes), 4 (frequently), 5 (usually), and 6 (always). We constructed variables for the first five (Public Services, Business License, Tax Collection, Government Contract, and Customs, respectively), and repeated our analysis to see if decentralization had different effects on corruption in these different settings. We did not expect to find similar results for corruption of the courts, since the arguments that apply to executive officials fit less well in this case. As a check to increase confidence that some unobserved third factor is not driving the results, we also ran regressions for the courts variable, and show that the results for executive officials do not extend to the courts.

\subsection{Firm-level control variables}

In our regressions, we include dummy variables for firms’ ownership. The variable State Ownership equals 1 if any government agency or state body has a financial stake in ownership of the firm, 0 otherwise. Foreign Ownership equals 1 if a foreign company or individual has a financial stake in ownership of the firm, 0 otherwise. The excluded category consists of firms completely owned by domestic private businesses or individuals. We expect that private firms are more vulnerable to bribe demands because they tend to have fewer government connections, less political influence, and weaker bargaining power (Svensson 2003). We also control for whether the given enterprise is an exporter (Exporter equals 1 if the firm exports, 0 otherwise) and for the enterprise's size (Firm Size equals the natural logarithm of firm sales). Finally, we include industry classification dummies (for manufacturing, services, agriculture, construction, other); to save space, we do not report the coefficients on these. 


\subsection{Country-level control variables}

Previous studies have found certain aspects of countries' economic structure, institutions, and culture to be significantly related to indicators of perceived corruption. La Porta et al. (1999), Ades and Di Tella (1999), Svensson (2005), and many others found robust evidence that higher GDP per capita was associated with lower perceived corruption. Treisman (2000) reported that Protestant religion, a history of British rule, and a long exposure to democracy were significantly linked to lower perceived corruption. Ades and Di Tella (1999) found that corruption was perceived to be greater in countries with large endowments of valuable natural resources (e.g. fuel and minerals) and in those that were less open to trade. Following previous practice, we control for the logarithm of countries' GDP per capita (GDP per Capita), imports of goods and services as a share of GDP (Imports), democracy in all years between 1950 and 2000 (Democratic), status as a former British colony (British Colony), share of minerals and fuels in manufacturing exports (Fuel), and the proportion of Protestants in the population (Protestant). To check for robustness, we try also including the number of years the country had been open to trade, a variable for presidential system, and an index of press freedom constructed by Freedom House. The empirical results were very robust to including these variables. ${ }^{13}$ Table 3 provides brief descriptions of the variables and data sources. Table 4 presents summary statistics.

[Tables 3 and 4 here]

\section{Results}

\subsection{Basic models}

We estimate two sets of regressions, one using the dependent variable BRIBE FREQUENCY, the other using BRIBE AMOUNT. In each case, we assume the enterprise's latent response can be described as follows:

${ }^{13}$ For brevity, we do not report these results here; both the number of years open to trade and the press freedom index were significantly associated with lower corruption. 


$$
\begin{gathered}
\text { DEPVAR }_{i, j}=\alpha+\beta^{\prime} \text { Decentralization Measures }_{j}+\alpha_{1} \text { State }_{i, j}+\alpha_{2} \text { Foreign }_{i, j} \\
+\alpha_{3} \text { Exporter }_{i, j}+\alpha_{4} \text { Firm Size }_{i, j}+\alpha_{5} \text { Industry Dummies }_{i, j} \\
+\theta^{\prime}{\text { Country } \text { Controls }_{j}}+\varepsilon_{i, j}
\end{gathered}
$$

where $D_{E P V A R}, \in\left\{\right.$ BRIBE FREQUENCY $\left.{ }_{i, j}, B R I B E A M O U N T_{i, j}\right\}$. The $i$ and $j$ subscripts indicate firm and country, respectively. Unlike the latent variable, the observed dependent variables, BRIBE FREQUENCY $_{i, j}$ and BRIBE AMOUNT ${ }_{i, j}$, are polychotomous variables with a natural order. Specifically, the respondent classifies the frequency of informal payments or the total burden of bribes into 6 or 7 categories, with 5 or 6 threshold parameters, $\lambda_{s}$; $s$ is the number of the thresholds. We therefore use the ordered probit model to estimate the $\lambda$-parameters together with regression coefficients simultaneously. We use the standard maximum likelihood estimation with heteroskedasticity-robust standard errors. In addition, we cluster the standard errors by country, allowing the errors to be correlated across firms within the same country while still requiring them to be independent across countries ${ }^{14}$. The coefficients are the same but more significant when we do not allow for clustering and simply run a standard ordered probit under the assumption of independent observations.

We start by running a regression that just includes the number of tiers. We then run regressions for the other explanatory variables associated with particular arguments discussed in Section 3. In all of these, we control for the number of tiers since the way the distribution of powers and resources across tiers affects corruption is very likely to depend on the number of tiers. Finally, we show a model that combines all the statistically significant decentralization variables into an aggregate regression. ${ }^{15}$ Significance naturally decreases as more decentralization variables are included because some of the measures are correlated. We present the results in Tables 5 and 6 . Note that the number of observations falls in the regressions for BRIBE AMOUNT because of the higher non-response rate. Since enterprises in

\footnotetext{
14 Estimation with a very small number of clusters may cause potential problems in estimating standard errors. For instance, if the number of clusters is far less than the number of regressors in the model, the insufficient degrees of freedom may produce singular cluster-corrected covariance matrices of the coefficient estimates. In our models, the number of clusters is greater than 30 in most cases, so this should be less of a concern.

15 That is, excluding the Henderson measures of policy decentralization, since these are available for far fewer countries and would cause a sharp drop in the number of observations.
} 
only 60 out of the 80 countries reported bribery payment amounts, the sample size falls from more than 6,000 to about 4,000 .

Ordered probit coefficients do not simply measure the marginal effect of a one-unit increase in the independent variable on the dependent variable (although the signs and statistical significance of the coefficients can be interpreted in the same way as for linear regression). To give a sense of the size of the estimated effects, we compute the marginal impact of increased decentralization on the probabilities that respondents choose each of the six categories (from "never" to "always"), and show these in Table 7. For this, we use the coefficient estimates from a model that includes all the independent variables found to be significant in sparser regressions. Given the correlations between different decentralization indicators, this is a relatively conservative approach.

[Tables 5 and 6 here]

A first finding concerns the vertical structure of the state. Among firms in this survey, those located in countries with more administrative or governmental tiers reported that firms like theirs were expected to pay bribes more frequently and for larger amounts than did those in countries with a flatter government structure (Table 5). The coefficient on TIERS was significant in almost all regressions. The size of the effect of TIERS on corruption was also quite large. For instance, adding an additional tier increased the probability that a firm from that country "always needed to make informal payments to get things done" by 2.6 percentage points and decreased the probability that firms "never" had to make such payments by 6.7 percentage points (Table 7). These effects are quite substantial given that only about nine percent of respondents said firms like theirs always made such payments and about 33 percent said they never did. The burden of bribery also appeared to be higher in countries with more tiers (Table 6). Bearing in mind the reduced country coverage in these regressions, the estimates nevertheless suggest that more tiers are associated with larger bribery payments.

[Table 7 here]

The number of tiers remains significant after adding more decentralization measures (e.g. fiscal decentralization, personnel decentralization, local autonomy) and control variables to the model in most 
specifications. Does the effect rise uniformly with the number of tiers or is there a threshold level of vertical complexity at which corruption increases? To examine this we broke down the tiers variable into separate dummies for "more than 1 tier," "more than 2 tiers” and so on. The results (not presented here for lack of space) showed that countries with 5 or 6 tiers had significantly more reported corruption than those with 3 or 4 tiers, which were, in turn, significantly more corrupt than those with 1 or 2 tiers.

These results parallel those found for indexes of perceived corruption by Treisman (2002). Although we hesitate to generalize beyond the sample given the non-random way in which countries were included (based on the availability of information on relevant variables), this does provide support for arguments that emphasize the problems of coordination and overgrazing in multi-tier structures.

The argument in Section 3.2 suggested that, conditional on some decisionmaking autonomy at the lowest tier, corruption should be less frequent and costly when the bottom units are smaller. Thus, we looked for interaction effects between local autonomy and bottom tier size. We controlled for bottom unit size, since it could have a direct impact on corruption. Using the general measures of subnational autonomy—federal structure, subnational decisionmaking rights—we found no statistically significant effect of bottom tier size. Using Henderson's measure of local authority over road construction, we found a surprising negative effect of bottom unit size: among those states where local governments participated in road construction, corruption was more frequent when the bottom units were smaller. This goes against the expectation that local governments would be more fearful of driving away businesses when units are smaller. It is possible that in larger local units, the rent-seeking of bureaucrats is more coordinated and this effect reduces corruption more than the disciplining effect of small jurisdiction size.

A third main finding concerns fiscal decentralization. In countries where subnational government revenues amounted to a larger share of GDP, firms reported less frequent demands for bribes, at least controlling for the number of tiers and total government revenue. A one standard deviation increase in subnational revenue as a share of GDP was associated with a 3 percentage point drop in the probability that firms would "always" have to make unofficial payments to get things done, along with a 7.7 percentage point increase in the probability that firms “never” have to make such payments (Table 7). 
This does provide some prima facie evidence that giving local governments a larger stake in tax revenues may reduce their incentive to demand bribes. ${ }^{16}$

However, there is reason to be cautious in interpreting this result. There was no evidence that the burden of bribery was lower in countries where subnational revenues were higher (coefficients were not significant in these regressions—see Table 6). ${ }^{17}$ And, interestingly, the reported frequency of bribery was also significantly lower in countries where central government revenues added up to a larger share of GDP holding subnational revenue constant. ${ }^{18}$ Larger central government revenues were linked not just to less frequent bribery but to a lower reported cost in bribes as well. Thus, one might read this as evidence of the beneficial incentive effect of giving governments at any level a greater stake in local revenue generation. We will return to this in discussing results for bribery in particular public services. However, there is also another interpretation. The level of revenue collection is clearly endogenous. It might be that excessive bribe extraction reduces government's ability to collect taxes, whether to fund subnational or central budgets. Larger government would then be a result of low corruption, not a cause of it. Lacking any reliable instruments, we can not rule out this alternative.

Some evidence supported the idea that greater decentralization of government personnel facilitates corruption. We found that a larger share of public employment at subnational levels was significantly associated with more frequent bribery, and the effect was larger controlling for the level of local revenues. Greater personnel decentralization was also associated with a greater burden of bribery (Table 6), although this result became insignificant when more decentralization variables were included. ${ }^{19}$ We also used an alternative personnel decentralization measure - the number of subnational employees per capita—since what matters for corruption may be the ratio of local officials to local residents. This, too,

\footnotetext{
16 In Fan, Lin and Treisman (2008) we tried some other commonly-used fiscal decentralization measures (i.e. subnational tax revenue as a percentage of total tax revenue and subnational government expenditure as a percentage of total government expenditure), and we found the subnational revenue share to be negatively and statistically significantly associated with the frequency of corruption, but the subnational expenditure share was not significant.

17 Besides, in regressions that do not control for the number of tiers, subnational revenues are not significantly related to the frequency of bribery and are even significantly positively related to the bribery amount.

18 Holding the subnational revenues constant, the total revenues variable picks up the effect of central revenues.

19 These regressions also controlled for total public employment as a share of the labor force.
} 
was significant, suggesting that higher staff levels in local government correlate with more frequent corruption (Tables 5 and 6, column 9).

Other measures of decentralization—-federal structure, subnational autonomy, elections at bottom and second lowest tiers—-had no statistically significant impact on corruption. ${ }^{20}$ For the indicators of policymaking decentralization, this could, of course, result from the imprecision of the measures we were able to construct. The lack of evidence that local elections reduced bribery might reflect the counter-effects suggested in Section 3.3. Local elections may be manipulated by local elites; voters may be ill-informed or intimidated; or voters may choose to vote on other issues or fail to coordinate to throw corrupt incumbents out of office. In some centralized countries, national elections may effectively motivate central incumbents to discipline their local agents. At the same time, deadlock and burden-shifting between elected central and local officials may enable all levels to shirk responsibility for poor governance. $^{21}$

The firm and country control variables also yield some interesting results. In all specifications, state-owned firms were less likely than their privately-owned counterparts to pay bribes, and the amount they reported paying was significantly lower. Other things equal, state-owned firms were 4.7 percentage points less likely than domestic private firms to say they “always” needed to make unofficial payments, and 20 percentage points more likely to say they "never" needed to do so. The coefficients on foreign ownership were negative and statistically significant in 6 out of 9 models for the frequency of bribery (although usually not significant for the amount of bribery), suggesting a corruption-reducing effect of foreign ownership, although a much smaller one than for state ownership. These results are consistent with the view that firms with more government connections and bargaining power are less vulnerable to predatory bribe-extraction. Larger firms also appeared to pay a smaller percentage of revenues in bribes, which might mean that officials tend to charge lump sum amounts in bribes for services rather than to

\footnotetext{
${ }^{20}$ The coefficient on our dummy for bottom tier elections was actually positive, although not significant at conventional levels.

${ }^{21}$ This result is consistent with Olken (2007), who found that increasing grassroots participation in monitoring the expenditures of road projects in Indonesian villages had little impact on corruption.
} 
levy payments proportional to firm income. Some of the country controls found significant in studies of perceived corruption indexes were also significant here. Firms in countries with higher GDP per capita reported less exposure to bribery. Measures of trade openness, raw materials exports, and Protestant religious tradition were also significant on occasion, but not at all robustly.

\subsection{Robustness checks and further exploration}

We checked the robustness of the findings in several ways.

First, we split the sample into countries that were relatively more developed (GDP per capita above the sample median of \$5,995) and those that were less developed (GDP per capita below the sample median). In richer countries, which tend to have more sophisticated legal environments, public officials may be constrained by mechanisms other than those associated with decentralized institutions. We might expect the impact of political decentralization to be stronger in the developing countries. As Table 8 (columns 1 to 6 ) shows, this was true for the number of tiers of government, which had a consistently significant positive impact on corruption in the less developed countries, but none in the more developed ones. Whereas our measures of policymaking decentralization were not significant in regressions for the full sample, subnational autonomy was now significantly associated with more frequent corruption in the subsample of less developed countries.

However, in other respects decentralization appeared to have significant effects in both more and less developed countries. Specifically, larger subnational revenues (as a percent of GDP) were associated with less frequent bribery in both subsamples. The corruption-increasing effect of greater local public employment (given subnational revenues) was also statistically significant in both subsamples. In addition, some corruption-reducing effects of centralization seemed to be stronger among the poorer countries. Larger central revenues (as a percent of GDP) significantly reduced corruption in the poorer, but not the richer, countries. (Recall, however, that causality might run from lower corruption to higher central revenues, rather than the reverse.) And, in contrast to the previous results, a larger central government bureaucracy was accompanied by less frequent bribery in the developing countries.

[Table 8 here] 
We then split the sample into "high" average corruption and "low" average corruption based on the sample median to see if the results are mainly driven by the variation among highly corrupt countries (see Table 8, columns 7-12). The main difference is that the number of tiers has a statistically significant effect only in the more corrupt sub-sample. Although local autonomy was not statistically significant in the full sample, it is significant--suggesting greater local autonomy is linked to more frequent bribery-in each of the subsamples. This effect is, in both subsamples, attenuated by the bottom unit size. Higher subnational revenues reduce corruption, and higher subnational government employment increases it, in both subsamples. Total government employment, which, controlling for the subnational employment share, picks up the effect of central government employment, was associated with lower corruption just among the more corrupt countries.

The fact that we do not have a balanced distribution of responses across the possible answers regarding corruption frequency might invalidate the ordered probit estimates; at the same time, a few outliers in one of the categories with a small number of responses might disproportionately influence the results. One technique used in previous studies to avoid these problems is to construct a corruption dummy that takes the value 0 for responses "never" "seldom” and "sometimes" and 1 for "frequently", “mostly,” and “always” (Beck et al., 2006; Barth et al. 2008). We do the same, and show the results in Table 9.

\section{[Table 9 here]}

In order to show the effects more directly, we calculate and report the marginal effects of the coefficients evaluated at the means of the independent variables from the Probit regressions. As can be seen in Table 9, the empirical results are very similar to our previous findings using ordered probit models. Specifically, the number of government tiers and the subnational share in government employment are positively associated with the likelihood of more pervasive corruption; larger bottom unit size and fiscal decentralization are associated with a likelihood of less pervasive corruption. Personnel decentralization is positively associated with the likelihood of more pervasive corruption, as indicated by the positive and statistically significant coefficient of subnational employment share. 
Finally, we examined how frequently respondents said bribery was required for particular purposes. We ran separate regressions for the reported frequency of bribery needed to: (1) get licenses and permits, (2) deal with taxes and tax collection, (3) obtain government contracts, (4) get connected to public utilities, (5) deal with customs/imports, and (6) deal with courts (see Table 10).

[Table 10 here]

Several conclusions emerge from this exploration. First, the corruption-inducing effect of a larger number of tiers appears particularly robust; a larger number of tiers was associated with more frequent bribery in almost all the regressions for executive officials. Second, in a way that is intuitively plausible, the effects of fiscal and public employment decentralization were strongest in the settings most likely to be dominated by subnational officials. Revenue decentralization was negatively related to bribery in licensing, utilities, government contracts, and customs/imports. The first two of these very often fall under the remit of local officials; government contracts are signed at all levels of government. Only the customs/imports result is less expected. The one public activity for which revenue decentralization was not significant was tax collection, which is often the responsibility of a centralized agency. Interestingly, for tax collection and customs — both matters often controlled by central officials—-the frequency of bribery was lower when the central government received a larger share of GDP as revenues, arguably giving it a stronger incentive to support growth. ${ }^{22}$ Somewhat surprisingly, for a given distribution of public employees across levels, the larger was total government employment, the lower was the reported frequency of bribery in for all five types of executive official. Controlling for the number of tiers, bribery for certain purposes was less frequent in federal states. We also report the results for bribery in "dealing with courts,” although we do not expect the same factors that influence corruption of executive officials to necessarily affect judges. This expectation is borne out: except for bottom unit size-larger local units were associated with less frequent judicial corruption — the decentralization variables that were significant for the executive officials—-tiers, fiscal and employment decentralization—had no effect on the courts.

${ }^{22}$ Of course, reverse causation is possible here too. 
This reduces the fear that corruption in all spheres and administrative complexity are both driven by some unobserved third factor.

Finally, in an early version of the paper (Fan, Lin and Treisman, 2008), we conducted a number of additional robustness tests. For example, one of the advances of this study is to use an experience-based measure of corruption. How do the results differ from those that would be obtained using measures of perceived corruption (i.e. the Transparency International Index and World Bank Corruption Control Index) as dependent variables? To assess this, Fan, Lin and Treisman (2008) present similar regressions using these country-level indexes, and we find that in these regressions too a higher number of tiers was associated with more corruption (i.e. a lower value of the indexes) in most models. As in some of the WBES regressions, larger bottom unit size was also associated with less corruption (contrary to the theoretical expectation). However, neither fiscal decentralization nor decentralization of government personnel were significant (which might be due to small sample size). Also, to check that the results are not being driven by a few outliers, Fan, Lin and Treisman (2008) presents scatter plots of the relationships between the corruption frequency and the main decentralization variables, controlling for all the control variables.

\section{Conclusion}

Previous studies, using subjective indexes of perceived corruption, have offered conflicting conclusions about how political and fiscal decentralization affect the frequency of bribery in countries around the world. Given the complicated, interacting effects that theorists have posited, it seems quite unlikely $a$ priori that there exists a simple, general relationship between decentralization and corruption that holds in different contexts and geographical settings. We do not suppose this paper will settle the question. Still, the data considered here have advantages over those previously analyzed. We examine a large-scale survey designed to elicit responses based on the concrete experience of the businessmen interviewed. Questions concerned corruption in particular settings as well as in general. We combine this with data on 
different types of decentralization that are more detailed and specific than those of previous papers, most of which have focused on just fiscal decentralization.

Among the countries and firms surveyed, several patterns stand out. In countries with a larger number of administrative or governmental tiers, reported bribery was both more frequent and more costly to firms. Other things equal, in a country with six tiers of government (such as Uganda) the probability that firms reported "never” being expected to pay bribes was .32 lower than the same probability in a country with two tiers (such as Slovenia). More tiers were associated with more frequent bribery over government contracts, connection to public utilities, and customs, but the effect was particularly strong for obtaining business licenses and over tax collection. The effect was strongest in developing countries, and was not significant in just the richer countries taken separately. As the number of tiers in a country gets high, this effect appears to overwhelm some factors otherwise related to the extent of bribery such as the size of firms or the country’s religious tradition.

Larger subnational bureaucracies were also associated with more frequent and costly bribery among the countries in this survey. The effect of higher subnational government employment was especially strong among more developed countries and over business licensing and taxation. This was not picking up just a general association between bureaucracy and corruption. In fact, given the size of the subnational bureaucracy, higher central government (or total) public employment was associated with less frequent reported bribery in all five spheres of activity, and especially in the developing countries taken separately.

Based on the survey examined, reducing the size of the lowest-level local units may also be a bad idea. Contrary to arguments that emphasize the disciplining effect of greater factor mobility, smaller local units were associated with more frequent and costly corruption, although this result was not robust to splitting the sample by income level and was not usually significant when respondents were asked about specific spheres of interaction with state officials.

By contrast, the responses were consistent with the notion that giving local governments a larger stake in locally generated income can reduce their bribe extraction. Other things equal, in a country (such 
as Finland) in which subnational revenues came to 15 percent of GDP, the probability that firms would say they "never” had to make unofficial payments to get things done was .14 higher than in countries (such as Luxembourg) where subnational revenues were only 5 percent of GDP. Subnational revenues were significant among both more and less developed countries taken separately, but the effect was stronger among the richer countries. Where central governments received larger revenues (as a percentage of GDP), reported bribery was also less frequent (as one might expect based on the incentive argument — central officials should also be motivated by a larger stake in marginal income), but the effect was smaller than for subnational revenues. Whereas greater subnational revenues were linked to lower corruption in business licensing, government contracts, utilities, and customs administration, larger central revenues were associated with less corruption in customs and tax collection, functions that are perhaps more often central responsibilities. However, whereas higher central government revenues were associated with a smaller reported burden of bribery, higher subnational government revenues were not significant. The effect of fiscal decentralization appears to be to reduce the frequency of bribery rather than the total cost of paying the bribes.

As usual in this sort of empirical study, there are caveats. Although the data we use are more detailed and precise than in previous explorations, they are still likely to contain some measurement error. In addition, the direction of causation is open to question for all the dimensions of decentralization examined but especially for the results concerning fiscal decentralization ${ }^{23}$. In more corrupt countries, official subnational revenues—and central revenues as well—might be lower because agents redirect their effort from tax collection to bribe extraction. Where officials are more predatory and less accountable, they might choose to create more complex structures of government, increasing the number of tiers, lower tier units, and subnational bureaucrats in order to provide benefits for their allies. These types of decentralization might also be caused by_rather than causes of — corruption. Lacking any reasonable

${ }^{23}$ In our study, the potential problem of endogeneity is much less of a concern than in a pure cross-country analysis because we are examining the impact of political decentralization on individual firms. It seems not very likely that an individual firm's view or perception about corruption will influence political decentralization nationwide (Beck et al., 2006; Barth et al. 2008). 
instruments for decentralization, we can suggest plausible interpretations of the patterns in the data, but cannot make confident claims about their causes.

Recognizing these limitations, the study does quite consistently support one line of argument—-that which emphasizes the danger of uncoordinated rent-seeking when government structures become more complex. The more tiers of government and the more local personnel with pockets to fill, the greater the danger that the rents of office will be "overgrazed”. Giving governments a greater stake in local income may reduce the motivation to extract bribes, although it could be just that more honest officials collect tax revenues more effectively, producing the same correlation. How generally applicable such findings are will become clearer as they are supplemented by further research examining other experience-based measures of corruption. 


\section{References}

Acemoglu, D., Johnson, S., 2005. “Unbundling institutions,” Journal of Political Economy 113 (5), 949-995.

Ades, Alberto and Rafael Di Tella. 1999. "Rents, Competition and Corruption,” American Economic Review 89 (4), 982-993.

Arikan, G. Gulsun. 2004. “Fiscal Decentralization: A Remedy for Corruption?” International Tax and Public Finance 11 (2), 175-195.

Ayyagari, M., Demirguc-Kunt, A., Maksimovi, V., 2007. "How well do institutional theories explain firms’ perceptions of property rights?” Review of Financial Studies, forthcoming

Bardhan, Prahab and Dilip Mookherjee. 2000. "Capture and Governance at Local and National Levels,” American Economic Review 90 (2),.135-139.

Barro, Robert J. and Rachel M. McCleary. 2005. “Which Countries Have State Religions?” Quarterly Journal of Economics 120(4), 1331-1370.

Barth, James, Lin Chen, Lin Ping and Song Frank, 2008. "Corruption in bank lending to firms: Cross-country micro evidence on the beneficial role of competition and information sharing," Journal of Financial Economics, forthcoming.

Beck, T., Demirguc-Kunt, A., Maksimovic, V., 2005. "Financial and legal constraints to firm growth: Does size matter?” Journal of Finance 60, 137-77.

Beck, Thorsten, Ash Demirguc-Kunt, and Ross Levince (2006), "Bank Supervision and Corruption in Lending,” Journal of Monetary Economics 53 (8), 2131-2163.

Berkowitz, Daniel and Wei Li. 2000. "Tax Rights in Transition Economies: A Tragedy of the Commons?” Journal of Public Economics 76 (3),.369-398.

Besley, Timothy and Coate Stephen, 2003. "Elected Versus Appointed Regulators: Theory and Evidence," Journal of the European Economic Association 1(5), 1176-1206.

Brennan, Geoffrey and James M. Buchanan. 1980. The Power to Tax: Analytical Foundations of a Fiscal Constitution, New York: Cambridge University Press.

Breton, Albert. 1996. Competitive Governments: An Economic Theory of Politics and Public Finance, New York: Cambridge University Press.

Cai, Hongbin and Daniel Treisman. 2004. "State Corroding Federalism,” Journal of Public Economics 88 (3-4),.819-843.

Cai, Hongbin and Daniel Treisman. 2005. "Does Competition for Capital Discipline Governments? Decentralization, Globalization, and Public Policy,” American Economic Review 95 (3), 817-830.

Dahl, Robert. 1986. "Federalism and the Democratic Process," in Dahl, Democracy, Identity, and Equality, Oslo: Norwegian University Press, pp.114-126. 
De Mello, Luiz R. Jr. and Matias Barenstein. 2001. "Fiscal Decentralization and Governance: A Cross-Country Analysis,” IMF Working Paper 01/71, Washington DC: IMF.

Djankov, Simeon, Rafael La Porta, Florencio López de Silanes, and Andrei Shleifer, 2003. “Courts,” Quarterly Journal of Economics 118, 453-517.

Elazar, Daniel J. 1995. “From Statism to Federalism: A Paradigm Shift,” Publius 25 (2), 5-18.

Enikolopov, Ruben and Ekaterina Zhuravskaya. 2007. "Decentralization and political institutions”, Journal of Public Economics 91, 2261-2290.

Fan, C. Simon, Chen Lin and Daniel Treisman, 2008. "Political decentralization and corruption: Evidence from around the world,” mimeo, Department of Political Science, UCLA.

Fisman, Raymond and Roberta Gatti. 2002. "Decentralization and Corruption: Evidence Across Countries,” Journal of Public Economics 83 (3), 325-345.

Goldsmith, Arthur A. 1999. "Slapping the Grasping Hand: Correlates of Political Corruption in Emerging Markets,” American Journal of Economics and Sociology 58 (4),.865-886.

Hayek, Friedrich. 1939. “The Economic Conditions of Interstate Federalism,” New Commonwealth Quarterly, 5, 2, pp.131-49, reprinted in Friedrich Hayek, Individualism and Economic Order, University of Chicago Press: 1948, pp.255-272.

Hellman, J., Jones, G., Kaufman, D., Schankerman, M., 2000. "Measuring governance and state capture: The role of bureaucrats and firms in shaping the business environment," European Bank for Reconstruction and Development, WP \#51.

Henderson, J. Vernon. 2000. “The Effects of Urban Concentration on Economic Growth,” NBER Working Paper No. 7503.

Huther, Jeff, and Anwar Shah. 1998. "Applying a Simple Measure of Good Governance to the Debate on Fiscal Decentralization,” Washington, DC: World Bank.

Jin, Hehui, Yingyi Qian and Barry R. Weingast. 2005. "Regional Decentralization and Fiscal Incentives: Federalism, Chinese Style,” Journal of Public Economics 89 (9-10), 1719-1742.

Johnson, Simon, John McMillan, and Christopher Woodruff. 2002. "Property Rights and Finance,” American Economic Review 92 (5), 1335-1356.

Keen, Michael and Christos Kotsogiannis. 2002. "Does Federalism Lead to Excessively High Taxes,” American Economic Review 92 (1),.363-370.

Kunicová, Jana and Susan Rose-Ackerman. 2005. "Electoral Rules and Constitutional Structures as Constraints on Corruption,” British Journal of Political Science 35 (4),.573-606.

La Porta, Rafael, Florencio Lopez-de-Silanes, Andrei Shleifer and Robert W. Vishny. 1999. "The Quality of Government,” Journal of Law, Economics and Organization 15 (1), 222-279.

Montinola, Gabriella, Yingyi Qian, and Barry R. Weingast. 1995. "Federalism, Chinese Style: The Political Basis for Economic Success,” World Politics 48 (1), 50-81. 
Myerson, Roger. 2006. “Federalism and Incentives for Success of Democracy,” Quarterly Journal of Political Science 1 (1), 3-23.

Olken, Benjamin A. 2007. "Monitoring Corruption: Evidence from a Field Experiment in Indonesia," Journal of Political Economy 115 (2), 200-249.

Olken, Benjamin A. and Patrick Barron. 2007. "The Simple Economics of Extortion: Evidence from Trucking in Aceh,” NBER Working Paper No. 13145.

Prud'homme, Remy. 1995. “On the Dangers of Decentralization,” World Bank Research Observer 10 (2),.201-220.

Reinikka, Ritva and Svensson, Jakob, 2006. "Using Micro-Surveys to Measure and Explain Corruption,” World Development 34, 359-379.

Riker, William H. 1964. Federalism: Origin, Operation, Significance, Boston: Little Brown.

Salmon, Pierre. 1987. "Decentralization as an Incentive Scheme,” Oxford Review of Economic Policy 3 (2),.24-43.

Schiavo-Campo, Salvatore, Giulio de Tommaso and Amitabha Mukherjee. 1997. An International Statistical Survey of Government Employment and Wages, Washington DC: The World Bank, PRWP 1806.

Seabright, Paul. 1996. “Accountability and decentralisation in government: An incomplete contracts model,” European Economic Review 40 (1), 61-89.

Shleifer, Andrei and Robert W. Vishny. 1993. “Corruption,” Quarterly Journal of Economics 108 (3), 599-618.

Spengler, Joseph J.. 1950. “Vertical Integration and Antitrust Policy,” Journal of Political Economy 58 (4),.347-352.

Stepan, Alfred. 2001. Arguing Comparative Politics, New York: Oxford University Press.

Svensson, Jakob. 2003. "Who Must Pay Bribes and How Much? Evidence from a Cross Section of Firms,” Quarterly Journal of Economics 118 (1), 207-230.

Svensson, Jakob. 2005. “Eight Questions about Corruption,” Journal of Economic Perspectives 19 (3), 19-42.

Tanzi, Vito. 1996. "Fiscal Federalism and Decentralization: A Review of Some Efficiency and Macroeconomic Aspects,” in World Bank, Annual World Bank Conference on Development Economics 1995, Washington DC: World Bank, pp.295-316.

Tiebout, Charles. 1956. “A Pure Theory of Local Expenditures,” Journal of Political Economy, 64 (4), 416-424.

Treisman, Daniel. 2000. “The Causes of Corruption: A Cross-National Study,” Journal of Public Economics 76 (3), 399-457. 
Treisman, Daniel. 2002. “Decentralization and the Quality of Government,” UCLA: manuscript, available at http://www.polisci.ucla.edu/faculty/treisman/.

Treisman, Daniel. 2006. "Fiscal decentralization, governance, and economic performance: a reconsideration,” Economics and Politics, 18 (2), 219-235.

Treisman, Daniel. 2007. "What Have We Learned About the Causes of Corruption from Ten Years of Cross-National Empirical Research?” Annual Review of Political Science 10, 211-44.

Zhuravskaya, Ekaterina, 2000. "Incentives to provide local public goods: fiscal federalism, Russian style,” Journal of Public Economics, 76 (3), 337-368. 
Figure 1. Subjective and Experience-Based Indicators of Corruption, 2000

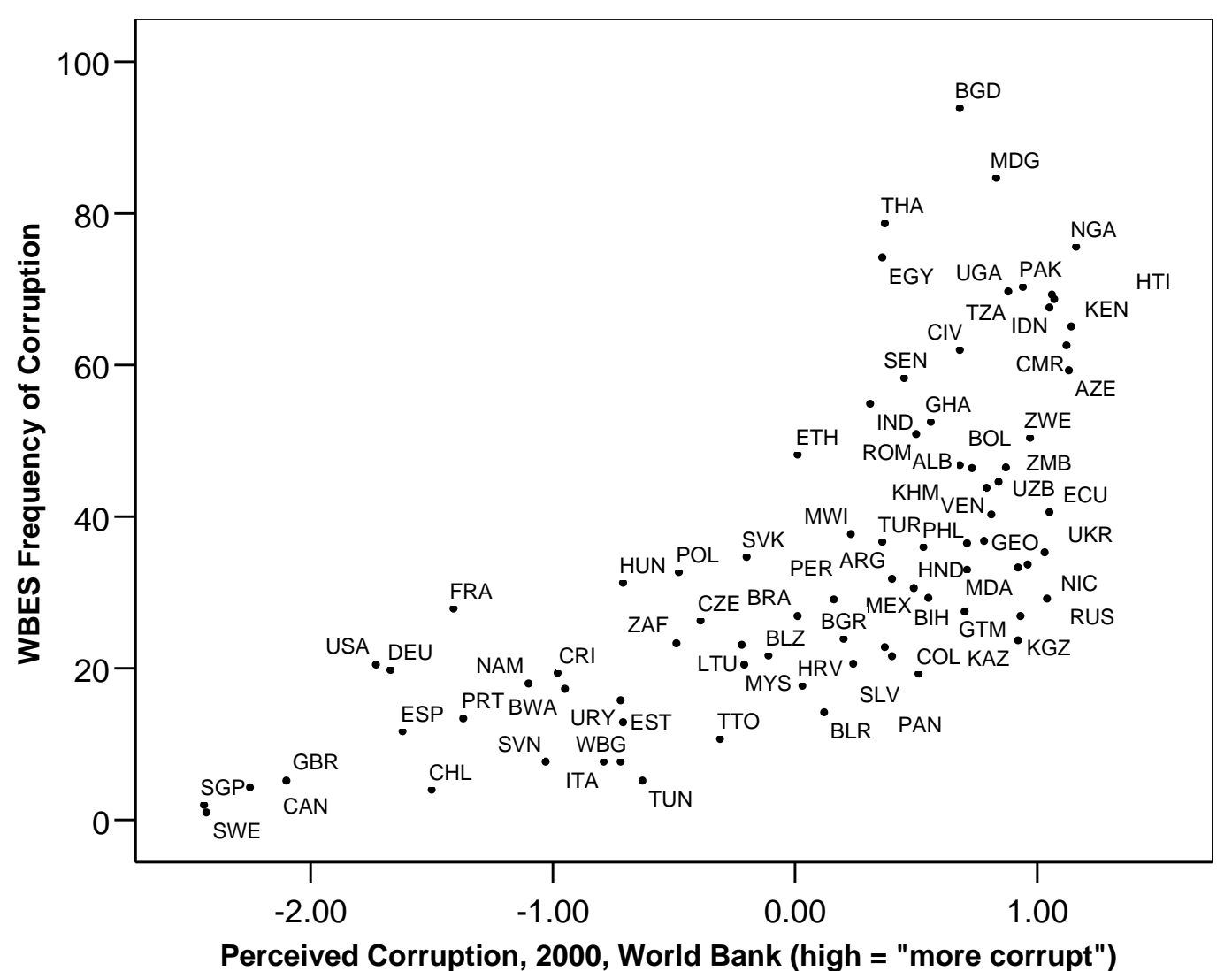

Note: WBES "Frequency of Corruption" is the percentage of respondents saying that firms in their line of business had to pay some irregular "additional payments" to get things done "always", "mostly", or "frequently" on the World Business Environment Survey. 
Table 1. New decentralization variables

\begin{tabular}{|c|c|c|c|c|c|c|}
\hline \multicolumn{7}{|c|}{ Number of tiers of government or administration (including central) } \\
\hline \multirow[b]{2}{*}{$N$} & \multicolumn{6}{|c|}{ Percent with } \\
\hline & 1 & 2 & 3 & 4 & 5 & 6 \\
\hline 156 & 1 & 5 & 35 & $45^{a}$ & 10 & 5 \\
\hline \multicolumn{7}{|c|}{ Number of bottom tier units } \\
\hline \multicolumn{7}{|c|}{ Percent with } \\
\hline$N$ & $\leq 100$ & $101-500$ & $501-1000$ & $1001-2000$ & $2001-5000$ & $>5000$ \\
\hline 126 & 15 & 28 & 12 & 11 & 15 & 19 \\
\hline \multicolumn{7}{|c|}{$\begin{array}{c}\text { Average size of bottom tier units, sq kms } \\
\text { (i.e., surface area divided by estimated number of bottom tier units) }\end{array}$} \\
\hline \multirow[b]{2}{*}{$N$} & \multicolumn{6}{|c|}{ Percent with } \\
\hline & $\leq 30$ & $31-100$ & $101-300$ & $301-1,000$ & $1,001-5,000$ & $>5,000$ \\
\hline 126 & 25 & 17 & 17 & 18 & 17 & 7 \\
\hline \multicolumn{7}{|c|}{$\begin{array}{l}\text { Autonomy } \\
\text { (constitution assigns at least one policy area exclusively to subnational governments or gives subnational } \\
\text { governments exclusive authority to legislate on matters not constitutionally assigned to any level) }\end{array}$} \\
\hline & \multicolumn{6}{|c|}{ Percent } \\
\hline$N$ & \multicolumn{3}{|c|}{ Yes } & \multicolumn{3}{|c|}{ No } \\
\hline 132 & \multicolumn{3}{|c|}{19} & \multicolumn{3}{|c|}{81} \\
\hline \multicolumn{7}{|c|}{ Executives at bottom tier directly elected or chosen by directly elected assembly } \\
\hline \multirow{3}{*}{$\frac{N}{114}$} & \multicolumn{6}{|c|}{ Percent } \\
\hline & & & \multicolumn{2}{|c|}{ No } & \multicolumn{2}{|c|}{ Partly } \\
\hline & & & & & & \\
\hline \multicolumn{7}{|c|}{ Executive at second lowest tier directly elected or chosen by directly elected assembly } \\
\hline & \multicolumn{6}{|c|}{ Percent } \\
\hline$N$ & \multicolumn{2}{|c|}{ Yes } & \multicolumn{2}{|c|}{ No } & \multicolumn{2}{|c|}{ Partly } \\
\hline 108 & \multicolumn{2}{|c|}{38} & \multicolumn{2}{|c|}{56} & \multicolumn{2}{|c|}{7} \\
\hline
\end{tabular}


Table 2. Correlations between decentralization variables (and In gdp per capita)

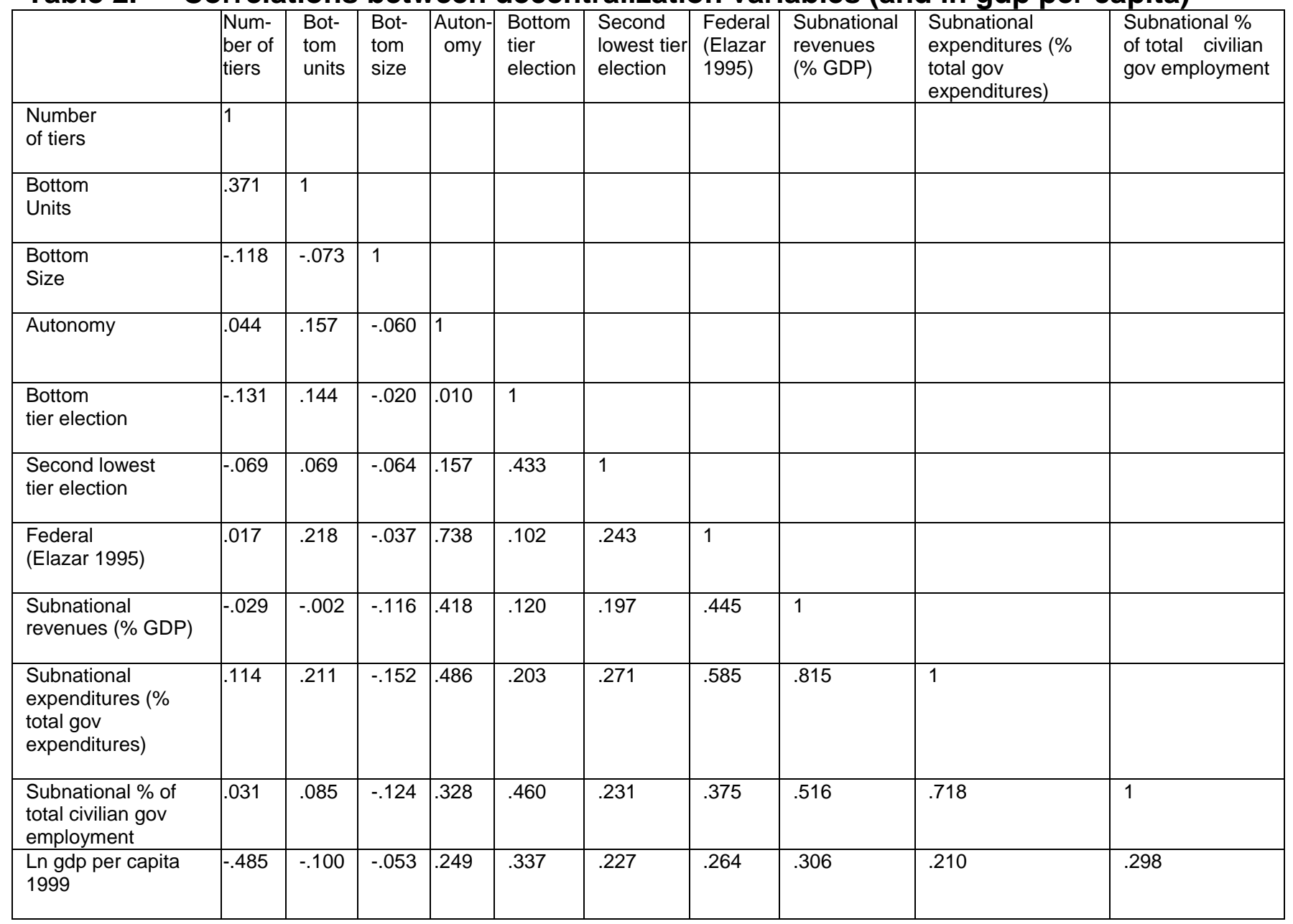


Table 3: Description and Sources of Key Variables

Source

WBES Countries Missing From Data

\begin{tabular}{|c|c|}
\hline Variable & Description \\
\hline \multicolumn{2}{|c|}{$\begin{array}{l}\text { Firm Characteristics and } \\
\text { Corruption Measures }\end{array}$} \\
\hline Bribe Frequency & $\begin{array}{l}\text { It is common for firms in my line of business } \\
\text { to have to pay some irregular "additional } \\
\text { payments" to get things done: (1) never, (2) } \\
\text { seldom, (3) sometimes. (4) frequently, (5) } \\
\text { mostly, (6) always. }\end{array}$ \\
\hline Bribe Amount & $\begin{array}{l}\text { On average, what percentage of revenues } \\
\text { do firms like yours typically pay per year in } \\
\text { unofficial payments to public officials: (1) } \\
0 \%,(2) \text { greater than } 0 \text { and less than } 1 \% \text {, } \\
\text { (3) } 1-1.99 \% \text {, (4) } 2-9.99 \% \text {, (5) } 10-12 \%,(6) \\
13-25 \%,(7) \text { over } 25 \% \text {. }\end{array}$ \\
\hline Foreign Ownership & $\begin{array}{l}\text { Dummy variable that equals } 1 \text { if any foreign } \\
\text { company or individual has a financial stake } \\
\text { in the ownership of the firm, } 0 \text { otherwise }\end{array}$ \\
\hline State Ownership & $\begin{array}{l}\text { Dummy variable that equals } 1 \text { if any } \\
\text { government agency or state body has a } \\
\text { financial stake in the ownership of the firm, } 0 \\
\text { otherwise }\end{array}$ \\
\hline Exporter & $\begin{array}{l}\text { Dummy variable that equals } 1 \text { if firm } \\
\text { exports, } 0 \text { otherwise. }\end{array}$ \\
\hline Firm Size & Natural logarithm of firm's sales \\
\hline Industry Dummies & $\begin{array}{l}\text { A series of dummy variables that represent } \\
\text { the firms' industries (Manufacturing, } \\
\text { Construction, Service, Agriculture, and } \\
\text { Others) }\end{array}$ \\
\hline \multicolumn{2}{|c|}{$\begin{array}{l}\text { Political and Fiscal } \\
\text { Decentralization Measures }\end{array}$} \\
\hline Tiers & $\begin{array}{l}\text { Number of tiers of government. } \\
\text { A tier is coded as a "tier of government" if } \\
\text { state executive body at that level }\end{array}$ \\
\hline
\end{tabular}

Firm Characteristics and

Corruption Measures to have to pay some irregular "additional payments" to get things done: (1) never, (2) seldom, (3) sometimes. (4) frequently, (5)

On average, what percentage of revenues

(4) $2-9.9 \%$, (5) $10-12 \%,(6)$

$3-25 \%$, (7) over $25 \%$.

variable that equals 1 if in the own or individual has a financial stake

Dummy variable that equals 1 if any Dency or state body has a inancial stake in the ownership of the firm, 0 orts, 0 otherwise.

state executive body at that level
World Business Environment Survey (WBES)

World Business Environment Survey (WBES)

World Business Environment Survey (WBES)

World Business Environment Survey (WBES)

World Business Environment Survey (WBES)

World Business Environment Survey (WBES)

World Business Environment Survey (WBES)

480 sources, detailed in Fan, Lin and Treisman (2008)
Belize, Cote d'Ivoire, West Bank-Gaza 
(1) was funded from the public budget, (2) had authority to administer a range of public services, and (3) had a territorial jurisdiction.

Federalism

Bottom Unit Size

Autonomy

Bottom Tier Election

Second Lowest Tier Election
Dummy variable that takes the value 1 if the country is classified as "federal", 0 otherwise.

Average size of bottom tier units, thousand sq kms (i.e., surface area divided by estimated number of bottom tier units)

Dummy variable that takes the value 1 if (1) constitution reserves decisionmaking on at least one topic exclusively to subnational

legislatures and/or (2) constitution assigns to subnational legislatures exclusive right to legislate on issues that it does not specifically assign to one level of government.

Variable that takes the value: 1 if executives at bottom tier are directly elected or chosen by directly elected assembly; 0 if executives at bottom tier are appointed by the officials in higher tier government unit; 0.5 if some of the executives are appointed while some of them are elected.

Variable that takes the value: 1 if executives at second lowest tier are directly elected or chosen by directly elected assembly; 0 if executives at second lowest tier are appointed by the officials in higher tier government unit; 0.5 if some of the executives are appointed while some of them are elected.

\section{Elazar (1995)}

480 sources, detailed in Fan, Lin and Treisman (2008)

\section{Constitutions of countries in data} set

480 sources, detailed in Fan, Lin and Treisman (2008)

480 sources, detailed in Fan, Lin and Treisman (2008)
Belize, Cote d'Ivoire, West Bank-Gaza

Belize, Cameroon, China, Cote d'Ivoire, Kenya, Nigeria, Senegal, Singapore, Tanzania, West Bank-Gaza

Belize, Botswana, Cameroon, Dominican Rep, Ecuador, El

Salvador, Guatemala, Honduras,

Nicaragua, Nigeria, Panama,

Tanzania, Ukraine, Uruguay, West Bank-Gaza

Armenia, Azerbaijan, Bangladesh, Belize, Botswana, Cambodia,

Cameroon, China, Cote d'Ivoire, Ethiopia, Ghana, Guatemala, India, Madagascar, Malawi, Moldova,

Pakistan, Singapore, West Bank-Gaza

Armenia, Azerbaijan, Belize, Cambodia, Cameroon, China, Cote d'Ivoire, Ethiopia, Ghana, Guatemala, India, Madagascar, Malawi, Moldova, Nicaragua, Pakistan, Singapore, Slovenia, Thailand, Trinidad Tobago, Uruguay, West Bank-Gaza, Zimbabwe 
Subnational Revenues

Subnational government employment share:

Total Government Revenues

Total Government

Employment

Other Macro Control Variables GDP per Capita
Sub-national revenues (\% of GDP), average 1994-2000, available years, from World

Bank Decentralization Indicators,

constructed from IMF GFS

non-central government employment as \% of total government employment.

Total government revenues (\% of GDP), average 1994-2000, available years, from World Bank Decentralization Indicators constructed from IMF GFS

Total government employment as a share of labor force.

Schiavo Campo et al. 1997

Natural logarithm of country's GDP per capita in year 1999
World Bank Decentralization Indicators (2000)

Schiavo Campo et al. 1997

World Bank Decentralization Indicators (2000)

Bangladesh, Belize, Bosnia,

Cambodia, Cameroon, Cote d'Ivoire

Ecuador, Egypt, Ethiopia,

Guatemala, Haiti, Honduras,

Madagascar, Malawi, Namibia,

Pakistan, Tanzania, Tunisia, Turkey, Venezuela, West Bank-Gaza

Azerbaijan, Bangladesh, Belize,

Bosnia, Brazil, Cambodia, Costa

Rica, Cote d'Ivoire, Czech Rep.

Dominican Rep., El Salvador,

Ethiopia, Guatemala, Haiti,

Kyrgyzstan, Madagascar, Malawi, Malaysia, Mexico, Namibia,

Nicaragua, Nigeria, Panama, Peru,

Romania, Slovenia, Trinidad Tobago,

Uzbekistan, West Bank-Gaza

Bangladesh, Belize, Bosnia,

Botswana, Cambodia, Cameroon,

Colombia, Cote d'Ivoire, Ecuador,

Egypt, El Salvador, Ethiopia

Guatemala, Haiti, Honduras,

Madagascar, Malawi, Namibia

Nigeria, Pakistan, Philippines,

Senegal, Singapore, Tanzania

Tunisia, Turkey, Uruguay,

Venezuela, West Bank-Gaza

Azerbaijan, Bangladesh, Belize,

Bosnia, Brazil, Cambodia, Costa

Rica, Cote d'Ivoire, Czech Rep.,

Dominican Rep., El Salvador,

Ethiopia, Guatemala, Haiti,

Kyrgyzstan, Madagascar, Malawi,

Mexico, Namibia, Nicaragua, Nigeria,

Panama, Peru, Romania, Slovenia,

Trinidad Tobago, Uzbekistan, West Bank-Gaza 
$\%$ of mineral fuels in manufacturing exports,

2000

imports of goods and services as \% of GDP,

Imports

Protestant

British Colony

dummy variable that takes the value 1 if the country is a former British colony, 0 otherwise.
Treisman (2000),

Przeworksi et al. (2000)

WDI 2006 (World Bank)

WDI 2007 (World Bank)

U.S. State Department Survey (2000), as in Barro and McCleary

(2005)

Belize, Cote d'Ivoire, West Bank-Gaza

Belize, Bosnia, Cote d'Ivoire,

Dominican Rep, Ethiopia, Haiti

Kyrgyzstan, Uzbekistan, West Bank-Gaza

Belize, Cote d'Ivoire, Singapore, West Bank-Gaza

West Bank-Gaza

Treisman (2000), with additional information from various sources
Belize, Cote d'Ivoire, West Bank-Gaza 
Table 4: Summary Statistics of Key Variables

\begin{tabular}{|c|c|c|c|c|c|}
\hline Variable & $\begin{array}{c}\text { Number of } \\
\text { Observations }\end{array}$ & Mean & $\begin{array}{l}\text { Standard } \\
\text { Deviation }\end{array}$ & Minimum & Maximum \\
\hline Bribe Frequency & 9130 & 2.914 & 1.683 & 1 & 6 \\
\hline Bribe Amount & 5246 & 2.427 & 1.542 & 1 & 7 \\
\hline Foreign Ownership & 9645 & 0.122 & 0.327 & 0 & 1 \\
\hline State Ownership & 9673 & 0.188 & 0.391 & 0 & 1 \\
\hline Exporter & 9463 & 0.356 & 0.479 & 0 & 1 \\
\hline Firm Size & 9087 & 9.982 & 7.803 & 0 & 25.328 \\
\hline Tiers & 9785 & 3.898 & 0.947 & 1 & 6 \\
\hline Federalism & 9785 & 0.219 & 0.414 & 0 & 1 \\
\hline Bottom Unit Size & 9114 & 1.739 & 8.862 & 0.002 & 83.143 \\
\hline Autonomy & 8462 & 0.299 & 0.458 & 0 & 1 \\
\hline Bottom Tier Election & 7858 & 0.775 & 0.405 & 0 & 1 \\
\hline $\begin{array}{l}\text { Second Lowest Tier } \\
\text { Election }\end{array}$ & 7032 & 0.539 & 0.484 & 0 & 1 \\
\hline $\begin{array}{c}\text { Subnational Revenues } \\
\text { (\% of GDP) }\end{array}$ & 7714 & 6.070 & 5.128 & 0 & 23.418 \\
\hline $\begin{array}{l}\text { Subnational government } \\
\text { share of public } \\
\text { employment }\end{array}$ & 6741 & 40.132 & 19.890 & 0 & 92.857 \\
\hline Ln GDP per Capita & 9728 & 8.447 & 0.938 & 6.205 & 10.396 \\
\hline Democratic & 9785 & 0.126 & 0.332 & 0 & 1 \\
\hline Fuel & 9111 & 13.973 & 21.434 & 0.001 & 99.635 \\
\hline Imports (\% of GDP) & 9685 & 41.199 & 19.158 & 11.519 & 104.462 \\
\hline $\begin{array}{c}\text { Protestant } \\
\text { (\% of Population) }\end{array}$ & 9932 & 0.330 & 0.358 & 0 & 0.943 \\
\hline British Colony & 9683 & 0.207 & 0.405 & 0 & 1 \\
\hline
\end{tabular}

The countries in the survey are: Albania (3), Argentina(3), Armenia (3), Azerbaijan (3), Bangladesh (5), Belarus (4), Bolivia (4), Botswana (3), Brazil (4), Bulgaria (4), Cambodia (4), Cameroon (6), Canada (4), Chile (4), China (5), Colombia (3), Costa Rica (4), Croatia (3), Czech Republic (3), Dominican Rep. (3), Ecuador (4), Egypt (4.5), El Salvador (3), Estonia (5), France (4), Georgia (4), Germany (4), Ghana (6), Guatemala (4), Honduras (3), Hungary (3), India (5), Indonesia (5), Italy (4), Kazakhstan (4), Kenya (6), Lithuania (3), Madagascar (5), Malawi (4), Malaysia (3), Mexico (3), Moldova (3), Namibia (3), Nicaragua (4), Nigeria (4), Pakistan (4.5), Panama (4), Peru (4), Philippines (4), Poland (3), Portugal (4), Romania (3), Russia (4), Senegal (6), Singapore (1), Slovakia (4), Slovenia (2), South Africa (3), Spain (4), Sweden (3), Tanzania (6), Thailand (5), Tunisia (4), Turkey (4), UK (4), US (4), Uganda (6), Ukraine (4), Uruguay (2), Venezuela (4), Zambia (3) and Zimbabwe (5). Tiers of governments are in parentheses 
Table 5: Decentralization and Bribe Frequency

\begin{tabular}{|c|c|c|c|c|c|c|c|c|c|c|}
\hline \multirow{2}{*}{ Variable } & \multicolumn{10}{|c|}{ Model Specification } \\
\hline & $(1)$ & $(2)$ & $(3)$ & (4) & (5) & (6) & (7) & (8) & (9) & (10) \\
\hline Tiers & $\begin{array}{l}0.254 \\
{[0.006]^{\star \star \star}}\end{array}$ & $\begin{array}{l}0.263 \\
{[0.007]^{\star \star \star}}\end{array}$ & $\begin{array}{l}0.216 \\
{[0.043]^{\star \star}}\end{array}$ & $\begin{array}{l}0.173 \\
{[0.152]}\end{array}$ & $\begin{array}{l}0.108 \\
{[0.408]}\end{array}$ & $\begin{array}{l}0.077 \\
{[0.351]}\end{array}$ & $\begin{array}{l}0.266 \\
{[0.000]^{\star \star \star}}\end{array}$ & $\begin{array}{l}0.334 \\
{[0.001]^{\star \star \star}}\end{array}$ & $\begin{array}{l}0.309 \\
{[0.002]^{\star \star \star}}\end{array}$ & $\begin{array}{l}0.209 \\
{[0.014]^{\star \star}}\end{array}$ \\
\hline Federal & & $\begin{array}{l}0.012 \\
{[0.940]}\end{array}$ & & & & & & & & \\
\hline Federal X Bottom Unit Size & & $\begin{array}{l}-0.059 \\
{[0.654]}\end{array}$ & & & & & & & & \\
\hline Bottom Unit Size & & $\begin{array}{l}-0.004 \\
{[0.110]}\end{array}$ & $\begin{array}{l}-0.055 \\
{[0.044]^{\star \star}}\end{array}$ & $\begin{array}{l}-0.192 \\
{[0.123]}\end{array}$ & $\begin{array}{l}-0.283 \\
{[0.066]^{\star}}\end{array}$ & & & & & $\begin{array}{l}-0.032 \\
{[0.506]}\end{array}$ \\
\hline Autonomy & & & $\begin{array}{l}0.036 \\
{[0.829]}\end{array}$ & & & & & & & \\
\hline Autonomy X Bottom Unit Size & & & $\begin{array}{l}0.05 \\
{[0.678]}\end{array}$ & & & & & & & \\
\hline Local Road Construction & & & & $\begin{array}{l}-0.143 \\
{[0.262]}\end{array}$ & & & & & & \\
\hline $\begin{array}{l}\text { Local Road Construction X Bottom } \\
\text { Unit Size }\end{array}$ & & & & -0.309 & & & & & & \\
\hline & & & & {$[0.035]^{\star \star}$} & & & & & & \\
\hline Local Police & & & & & $\begin{array}{l}-0.137 \\
{[0.533]}\end{array}$ & & & & & \\
\hline Local Police X Bottom Unit Size & & & & & $\begin{array}{l}-0.239 \\
{[0.436]}\end{array}$ & & & & & \\
\hline Bottom Tier Election & & & & & & $\begin{array}{l}0.141 \\
{[0.268]}\end{array}$ & & & & \\
\hline Second Lowest Tier Election & & & & & & $\begin{array}{l}-0.05 \\
{[0.659]}\end{array}$ & & & & \\
\hline Subnational Revenues & & & & & & & $\begin{array}{l}-0.025 \\
{[0.034]^{\star \star}}\end{array}$ & & & $\begin{array}{l}-0.044 \\
{[0.000]^{\star \star \star}}\end{array}$ \\
\hline Total Government Revenues & & & & & & & $\begin{array}{l}-0.018 \\
{[0.032]^{\star \star}}\end{array}$ & & & $\begin{array}{l}-0.02 \\
{[0.028]^{\star \star}}\end{array}$ \\
\hline $\begin{array}{l}\text { Subnational Government } \\
\text { Employment Share }\end{array}$ & & & & & & & & 0.005 & & 0.008 \\
\hline & & & & & & & & {$[0.082]^{*}$} & & {$[0.032]^{\star *}$} \\
\hline
\end{tabular}


0.124

$[0.039]^{\star \star}$

Central Government Employment

Ratio (\% of Population)

\section{State Ownership}

Foreign Ownership

Exporter

Firm Size

\section{GDP per Capita}

Democratic

Fuel

Imports

Protestant

British Colony

Industry Dummies

Number of Countries

$\begin{array}{lll} & & \\ & & \\ & & \\ & & \\ & & \\ & & \\ -0.534 & -0.536 & -0.558 \\ {[0.000]^{\star \star \star}} & {[0.000]^{\star \star \star}} & {[0.000]^{\star \star \star}} \\ -0.07 & -0.065 & -0.073 \\ {[0.149]} & {[0.190]} & {[0.179]} \\ 0.054 & 0.059 & 0.068 \\ {[0.155]} & {[0.119]} & {[0.106]} \\ -0.008 & -0.008 & -0.004 \\ {[0.284]} & {[0.323]} & {[0.662]} \\ -0.291 & -0.277 & -0.349 \\ {[0.000]^{\star \star \star}} & {[0.000]^{\star \star \star}} & {[0.000]^{\star \star \star}} \\ 0.006 & -0.026 & -0.066 \\ {[0.967]} & {[0.879]} & {[0.702]} \\ 0.0005 & 0.0001 & -0.002 \\ {[0.833]} & {[0.974]} & {[0.614]} \\ 0.0004 & 0.000 & 0.0002 \\ {[0.902]} & {[0.996]} & {[0.961]} \\ -0.864 & -0.906 & -0.653 \\ {[0.037]^{\star \star}} & {[0.032]^{\star \star}} & {[0.163]} \\ -0.028 & -0.011 & -0.074 \\ {[0.825]} & {[0.929]} & {[0.588]} \\ \text { yes } & \text { yes } & \text { yes } \\ 67 & 63 & 54 \\ 6676 & 6527 & 5820\end{array}$

\begin{tabular}{ll} 
& \\
& \\
& \\
& \\
& \\
-0.554 & -0.561 \\
{$[0.000]^{\star \star \star}$} & {$[0.000]^{\star \star \star}$} \\
-0.155 & -0.16 \\
{$[0.000]^{\star \star \star}$} & {$[0.000]^{\star \star \star}$} \\
0.017 & 0.023 \\
{$[0.658]$} & {$[0.563]$} \\
-0.002 & 0.002 \\
{$[0.803]$} & {$[0.842]$} \\
-0.414 & -0.395 \\
{$[0.001]^{\star \star \star}$} & {$[0.007]^{\star \star \star}$} \\
0.044 & -0.015 \\
{$[0.804]$} & {$[0.938]$} \\
0.001 & 0.002 \\
{$[0.722]$} & {$[0.626]$} \\
0.004 & 0.003 \\
{$[0.237]$} & {$[0.467]$} \\
-0.369 & -0.347 \\
{$[0.378]$} & {$[0.381]$} \\
-0.19 & -0.125 \\
{$[0.319]$} & {$[0.503]$} \\
yes & yes \\
30 & 30 \\
3499 & 3499 \\
\hline 0
\end{tabular}

\begin{tabular}{|c|c|c|c|c|}
\hline & & & 0.124 & \\
\hline & & & {$[0.039]^{\star \star}$} & \\
\hline & & & 0.027 & \\
\hline & & & {$[0.767]$} & \\
\hline $\begin{array}{l}-0.587 \\
{[0.000]^{\star \star \star}}\end{array}$ & $\begin{array}{l}-0.505 \\
{[0.000]^{\star \star \star}}\end{array}$ & $\begin{array}{l}-0.586 \\
{[0.000]^{\star \star \star}}\end{array}$ & $\begin{array}{l}-0.597 \\
{[0.000]^{\star \star \star}}\end{array}$ & $\begin{array}{l}-0.557 \\
{[0.000]^{\star \star \star}}\end{array}$ \\
\hline-0.105 & -0.127 & -0.1 & -0.114 & -0.131 \\
\hline$[0.024]^{\star \star}$ & {$[0.001]^{\star \star *}$} & {$[0.005]^{\star \star \star}$} & {$[0.002]^{\star \star \star}$} & {$[0.000]^{\star \star \star}$} \\
\hline 0.037 & 0.055 & 0.036 & 0.026 & 0.065 \\
\hline [0.297] & {$[0.064]^{\star}$} & [0.269] & [0.469] & {$[0.031]^{\star \star}$} \\
\hline-0.016 & -0.02 & -0.006 & -0.006 & -0.012 \\
\hline$[0.034]^{\star *}$ & {$[0.003]^{\star \star \star}$} & [0.432] & [0.432] & {$[0.049]^{\star \star}$} \\
\hline-0.35 & -0.105 & -0.317 & -0.32 & -0.131 \\
\hline$[0.000]^{\star \star *}$ & {$[0.205]$} & {$[0.000]^{\star \star *}$} & {$[0.000]^{\star \star *}$} & {$[0.217]$} \\
\hline 0.016 & 0.031 & -0.191 & -0.141 & 0.19 \\
\hline [0.936] & [0.864] & [0.297] & [0.467] & [0.351] \\
\hline 0.000 & 0.000 & -0.003 & -0.003 & 0.003 \\
\hline [0.989] & [0.913] & [0.253] & [0.292] & [0.518] \\
\hline-0.003 & 0.000 & -0.001 & -0.001 & 0.002 \\
\hline [0.127] & [0.907] & {$[0.742]$} & [0.658] & [0.537] \\
\hline-0.376 & -0.036 & -0.814 & -0.285 & 0.409 \\
\hline [0.506] & [0.931] & {$[0.116]$} & [0.581] & [0.378] \\
\hline 0.17 & -0.155 & -0.118 & -0.15 & -0.257 \\
\hline [0.405] & [0.294] & [0.545] & [0.356] & [0.202] \\
\hline yes & yes & yes & yes & yes \\
\hline 50 & 47 & 48 & 48 & 34 \\
\hline 4775 & 5270 & 4998 & 4979 & 4101 \\
\hline
\end{tabular}

Regressions run with ordered probit, based on standard maximum likelihood estimation, with heteroskedasticity-robust standard errors clustered by country. Detailed variable definitions and sources in Table 3. ${ }^{* *},{ }^{* *}$, and ${ }^{*}$ indicate significance at the $1 \%, 5 \%$, and $10 \%$ levels, respectively. P-values based on robust standard errors in parentheses. 
Table 6: Decentralization and Bribe Amount

\begin{tabular}{|c|c|c|c|c|c|c|c|c|c|c|}
\hline \multirow[b]{2}{*}{ Variable } & \multicolumn{10}{|c|}{ Model Specification } \\
\hline & (1) & (2) & (3) & (4) & (5) & (6) & (7) & (8) & (9) & (10) \\
\hline Tiers & $\begin{array}{l}0.462 \\
{[0.000]^{\star \star \star}}\end{array}$ & $\begin{array}{l}0.401 \\
{[0.008]^{\star \star \star}}\end{array}$ & $\begin{array}{l}0.319 \\
{[0.014]^{\star \star}}\end{array}$ & $\begin{array}{l}0.291 \\
{[0.075]^{*}}\end{array}$ & $\begin{array}{l}0.317 \\
{[0.088]^{*}}\end{array}$ & $\begin{array}{l}0.234 \\
{[0.171]}\end{array}$ & $\begin{array}{l}0.332 \\
{[0.003]^{\star \star \star}}\end{array}$ & $\begin{array}{l}0.616 \\
{[0.000]^{\star \star \star}}\end{array}$ & $\begin{array}{l}0.609 \\
{[0.000]^{\star \star \star}}\end{array}$ & $\begin{array}{l}0.560 \\
{[0.000]^{\star \star \star \star}}\end{array}$ \\
\hline Federal & & $\begin{array}{l}0.085 \\
{[0.789]}\end{array}$ & & & & & & & & \\
\hline Federal X Bottom Unit Size & & $\begin{array}{l}-0.009 \\
{[0.966]}\end{array}$ & & & & & & & & \\
\hline Bottom Unit Size & & $\begin{array}{l}-0.097 \\
{[0.225]}\end{array}$ & $\begin{array}{l}-0.462 \\
{[0.004]^{\star \star \star}}\end{array}$ & $\begin{array}{l}-0.316 \\
{[0.135]}\end{array}$ & $\begin{array}{l}-0.265 \\
{[0.146]}\end{array}$ & & & & & $\begin{array}{l}-0.069 \\
{[0.474]}\end{array}$ \\
\hline Autonomy & & & $\begin{array}{l}-0.033 \\
{[0.914]}\end{array}$ & & & & & & & \\
\hline Autonomy X Bottom Unit Size & & & $\begin{array}{l}0.342 \\
{[0.118]}\end{array}$ & & & & & & & \\
\hline Local Road Construction & & & & $\begin{array}{l}-0.159 \\
{[0.529]}\end{array}$ & & & & & & \\
\hline Local Road Construction X & & & & & & & & & & \\
\hline Bottom Unit Size & & & & $\begin{array}{l}-0.058 \\
{[0.818]}\end{array}$ & & & & & & \\
\hline Local Police & & & & & $\begin{array}{l}0.331 \\
{[0.340]}\end{array}$ & & & & & \\
\hline Local Police X Bottom Unit & & & & & & & & & & \\
\hline Size & & & & & $\begin{array}{l}-0.482 \\
{[0.276]}\end{array}$ & & & & & \\
\hline Bottom Tier Election & & & & & & $\begin{array}{l}0.012 \\
{[0.946]}\end{array}$ & & & & \\
\hline Second Lowest Tier Election & & & & & & $\begin{array}{l}0.033 \\
{[0.835]}\end{array}$ & & & & \\
\hline Subnational Revenues & & & & & & & $\begin{array}{l}0.018 \\
{[0.304]}\end{array}$ & & & \\
\hline Total Government Revenues & & & & & & & $\begin{array}{l}-0.036 \\
{[0.001]^{\star \star \star}}\end{array}$ & & & \\
\hline $\begin{array}{l}\text { Subnational Government } \\
\text { Employment Share }\end{array}$ & & & & & & & & 0.008 & & 0.007 \\
\hline
\end{tabular}


Total Government Employees

\begin{tabular}{|c|c|c|c|c|c|c|c|c|c|}
\hline & & & & & & & $\begin{array}{l}{[0.060]^{*}} \\
-0.004 \\
{[0.903]}\end{array}$ & & $\begin{array}{l}{[0.093]^{*}} \\
-0.003 \\
{[0.926]}\end{array}$ \\
\hline & & & & & & & & $\begin{array}{l}0.168 \\
{[0.129]}\end{array}$ & \\
\hline & & & & & & & & $\begin{array}{l}-0.009 \\
{[0.919]}\end{array}$ & \\
\hline $\begin{array}{l}-0.152 \\
{[0.016]^{\star \star}}\end{array}$ & $\begin{array}{l}-0.165 \\
{[0.007]^{\star \star \star}}\end{array}$ & $\begin{array}{l}-0.198 \\
{[0.003]^{\star \star \star}}\end{array}$ & $\begin{array}{l}-0.258 \\
{[0.000]^{\star \star \star}}\end{array}$ & $\begin{array}{l}-0.272 \\
{[0.000]^{\star \star \star}}\end{array}$ & $\begin{array}{l}-0.187 \\
{[0.002]^{\star \star \star}}\end{array}$ & $\begin{array}{l}-0.155 \\
{[0.019]^{\star \star}}\end{array}$ & $\begin{array}{l}-0.249 \\
{[0.001]^{\star \star \star}}\end{array}$ & $\begin{array}{l}-0.237 \\
{[0.002]^{\star \star \star}}\end{array}$ & $\begin{array}{l}-0.258 \\
{[0.001]^{\star \star \star}}\end{array}$ \\
\hline $\begin{array}{l}-0.062 \\
{[0.367]}\end{array}$ & $\begin{array}{l}-0.067 \\
{[0.323]}\end{array}$ & $\begin{array}{l}-0.106 \\
{[0.170]}\end{array}$ & $\begin{array}{l}-0.15 \\
{[0.083]^{\star}}\end{array}$ & $\begin{array}{l}-0.153 \\
{[0.076]^{\star}}\end{array}$ & $\begin{array}{l}-0.093 \\
{[0.215]}\end{array}$ & $\begin{array}{l}-0.158 \\
{[0.042]^{\star *}}\end{array}$ & $\begin{array}{l}-0.104 \\
{[0.172]}\end{array}$ & $\begin{array}{l}-0.139 \\
{[0.075]^{\star}}\end{array}$ & $\begin{array}{l}-0.109 \\
{[0.157]}\end{array}$ \\
\hline 0.071 & 0.074 & 0.096 & -0.001 & 0.003 & -0.019 & 0.032 & -0.001 & 0 & 0.001 \\
\hline [0.261] & {$[0.241]$} & [0.228] & [0.987] & [0.957] & [0.712] & {$[0.569]$} & [0.979] & [0.994] & [0.979] \\
\hline-0.066 & -0.061 & -0.05 & -0.044 & -0.037 & -0.077 & -0.073 & -0.062 & -0.062 & -0.058 \\
\hline$[0.000]^{\star \star \star}$ & {$[0.000]^{\star \star \star}$} & {$[0.000]^{\star \star *}$} & {$[0.004]^{\star * *}$} & {$[0.002]^{\star \star \star}$} & {$[0.000]^{\star \star \star}$} & {$[0.000]^{\star \star \star}$} & {$[0.000]^{\star \star *}$} & {$[0.000]^{\star \star *}$} & {$[0.000]^{\star * *}$} \\
\hline-0.319 & -0.317 & -0.351 & -0.513 & -0.611 & -0.549 & -0.149 & -0.521 & -0.552 & -0.503 \\
\hline$[0.009]^{\star \star \star}$ & {$[0.016]^{\star \star}$} & {$[0.014]^{\star \star}$} & {$[0.097]^{\star}$} & {$[0.064]^{*}$} & {$[0.000]^{\star \star *}$} & [0.329] & {$[0.000]^{\star \star \star}$} & {$[0.000]^{\star \star *}$} & {$[0.001]^{\star * *}$} \\
\hline-0.217 & -0.232 & -0.353 & -0.144 & -0.245 & -0.024 & -0.262 & -0.434 & -0.664 & -0.471 \\
\hline [0.484] & [0.439] & {$[0.264]$} & [0.779] & [0.669] & {$[0.934]$} & {$[0.337]$} & {$[0.317]$} & [0.121] & [0.293] \\
\hline 0.002 & 0.003 & 0.004 & 0.008 & 0.007 & 0.003 & -0.002 & 0.001 & 0.002 & 0.002 \\
\hline [0.199] & [0.151] & [0.230] & {$[0.090]^{\star}$} & {$[0.074]^{\star}$} & [0.282] & [0.427] & {$[0.760]$} & [0.584] & [0.561] \\
\hline 0.003 & 0.003 & 0.002 & 0.008 & 0.007 & -0.001 & 0.007 & 0.004 & 0.002 & 0.004 \\
\hline [0.335] & [0.386] & [0.539] & {$[0.089]^{\star}$} & [0.199] & {$[0.760]$} & [0.114] & [0.433] & [0.558] & [0.475] \\
\hline-0.228 & -0.302 & 0.347 & 1.742 & 2.252 & 0.537 & 0.397 & 0.732 & 2.834 & 0.742 \\
\hline [0.796] & {$[0.726]$} & [0.666] & {$[0.057]^{\star}$} & {$[0.057]^{\star}$} & [0.640] & [0.644] & [0.461] & {$[0.002]^{\star \star \star}$} & [0.447] \\
\hline 0.132 & 0.102 & -0.007 & 0.071 & 0.038 & 0.338 & -0.202 & 0.008 & -0.024 & 0.053 \\
\hline [0.584] & [0.702] & [0.979] & [0.820] & [0.892] & [0.452] & [0.588] & [0.984] & [0.905] & [0.890] \\
\hline yes & yes & yes & yes & yes & yes & yes & yes & yes & yes \\
\hline 51 & 51 & 43 & 25 & 25 & 40 & 40 & 36 & 36 & 36 \\
\hline 4102 & 4102 & 3559 & 2221 & 2221 & 3019 & 3195 & 2950 & 2910 & 2950 \\
\hline
\end{tabular}

Subnational Government

Employment Ratio

(\% of Population)

0.168

Central Government

Employment Ratio

(\% of Population)

State Ownership

Foreign Ownership

Exporter

Firm Size

GDP per Capita

Democratic

Fuel

Imports

Protestant

British Colony

Industry Dummies

Number of Countries

Observations

Regressions run with ordered probit, based on standard maximum likelihood estimation, with heteroskedasticity-robust standard errors clustered by country.

Detailed variable definitions and sources in Table 3. ${ }^{* \star *},{ }^{\star *}$, and * indicate significance at the $1 \%, 5 \%$, and $10 \%$ levels, respectively. P-values based on robust standard errors in parentheses. 
Table 7: Magnitude of the Effects: Decentralization and Bribe Frequency

\begin{tabular}{|c|c|c|c|c|c|c|c|}
\hline & Change & $\begin{array}{c}1 \\
\text { Never }\end{array}$ & $\begin{array}{c}2 \\
\text { Seldom }\end{array}$ & $\begin{array}{c}3 \\
\text { Sometimes }\end{array}$ & $\begin{array}{c}4 \\
\text { Frequently }\end{array}$ & $\begin{array}{c}5 \\
\text { Mostly }\end{array}$ & $\begin{array}{c}6 \\
\text { Always }\end{array}$ \\
\hline \multirow[t]{2}{*}{ Tiers } & $\begin{array}{c}1 \text { standard deviation } \\
\text { increase }\end{array}$ & -0.0513 & -0.0102 & 0.0013 & 0.0160 & 0.0243 & 0.0198 \\
\hline & Marginal Effect & -0.0675 & -0.0134 & 0.0017 & 0.0212 & 0.0321 & 0.0260 \\
\hline \multirow{2}{*}{$\begin{array}{l}\text { Subnational } \\
\text { Revenue }\end{array}$} & $\begin{array}{c}1 \text { standard deviation } \\
\text { increase }\end{array}$ & 0.0771 & 0.0152 & -0.0019 & -0.0240 & -0.0366 & -0.0298 \\
\hline & Marginal Effect & 0.0141 & 0.0028 & -0.0004 & -0.0044 & -0.0067 & -0.0054 \\
\hline \multirow{2}{*}{$\begin{array}{c}\text { Subnational } \\
\text { Government } \\
\text { Employment Share }\end{array}$} & $\begin{array}{l}1 \text { standard deviation } \\
\text { increase }\end{array}$ & -0.0455 & -0.0090 & 0.0011 & 0.0142 & 0.0216 & 0.0175 \\
\hline & Marginal Effect & -0.0026 & -0.0005 & 0.0001 & 0.0008 & 0.0013 & 0.0010 \\
\hline State Ownership & from 0 to 1 & 0.2050 & 0.0143 & -0.0354 & -0.0662 & -0.0730 & -0.0447 \\
\hline Foreign Ownership & from 0 to 1 & 0.0438 & 0.0073 & -0.0029 & -0.0141 & -0.0195 & -0.0146 \\
\hline
\end{tabular}

Note: Figures in the table indicate the change in probability of a firm giving this answer associated with the indicated change in the value of the decentralization measure. The estimation is based on model 10 in Table 5. 
Table 8: Decentralization and Bribe Frequency in Different Sub-Samples

\begin{tabular}{|c|c|c|c|c|c|c|c|c|c|c|c|c|}
\hline \multirow[b]{3}{*}{ Variable } & \multicolumn{12}{|c|}{ Model Specifications } \\
\hline & \multicolumn{3}{|c|}{ More Developed Countries } & \multicolumn{3}{|c|}{ Less Developed Countries } & \multicolumn{3}{|c|}{ More Corrupt Countries } & \multicolumn{3}{|c|}{ Less Corrupt Countries } \\
\hline & (1) & $(2)$ & (3) & $(4)$ & $(5)$ & (6) & (7) & $(8)$ & $(9)$ & $(10)$ & (11) & $(12)$ \\
\hline \multirow{2}{*}{ Tiers } & 0.075 & -0.023 & 0.025 & 0.303 & 0.301 & 0.179 & 0.197 & 0.206 & 0.242 & 0.086 & -0.171 & 0.146 \\
\hline & [0.442] & [0.866] & [0.828] & {$[0.002]^{\star \star \star}$} & {$[0.048]^{\star \star}$} & {$[0.004]^{\star \star \star}$} & {$[0.014]^{\star \star}$} & {$[0.055]^{\star}$} & {$[0.000]^{\star \star \star}$} & {$[0.271]$} & {$[0.167]$} & [0.320] \\
\hline \multirow[t]{2}{*}{ Autonomy } & & 0.223 & & & 0.858 & & & 0.704 & & & 0.719 & \\
\hline & & [0.415] & & & {$[0.021]^{\star \star}$} & & & {$[0.000]^{\star \star \star}$} & & & {$[0.000]^{\star \star \star}$} & \\
\hline \multicolumn{13}{|l|}{ Autonomy X } \\
\hline \multirow[t]{2}{*}{ Bottom Unit Size } & & 0.256 & & & -0.166 & & & -0.582 & & & -0.352 & \\
\hline & & [0.358] & & & [0.281] & & & {$[0.000]^{\star \star \star}$} & & ‘ & {$[0.013]^{\star \star}$} & \\
\hline \multirow[t]{2}{*}{ Bottom Unit Size } & & -0.29 & & & -0.016 & & & -0.0003 & & & -0.033 & \\
\hline & & {$[0.011]^{\star \star}$} & & & [0.633] & & & {$[0.990]$} & & & [0.316] & \\
\hline \multicolumn{13}{|l|}{ Subnational } \\
\hline \multirow[t]{2}{*}{ Revenues } & & & -0.097 & & & -0.068 & & & -0.081 & & & -0.075 \\
\hline & & & {$[0.000]^{\star \star \star}$} & & & {$[0.000]^{\star \star \star}$} & & & {$[0.000]^{\star \star \star}$} & & & {$[0.000]^{\star \star \star}$} \\
\hline \multicolumn{13}{|l|}{ Total Government } \\
\hline \multirow[t]{2}{*}{ Revenues } & & & -0.006 & & & -0.024 & & & 0.002 & & & 0.006 \\
\hline & & & [0.470] & & & {$[0.001]^{\star \star \star}$} & & & [0.593] & & & [0.605] \\
\hline \multicolumn{13}{|l|}{ Subnational } \\
\hline \multirow[t]{2}{*}{ Employment Share } & & & 0.031 & & & 0.01 & & & 0.013 & & & 0.02 \\
\hline & & & {$[0.000]^{\star \star \star}$} & & & {$[0.000]^{\star \star \star}$} & & & {$[0.000]^{\star \star *}$} & & & {$[0.005]^{\star \star *}$} \\
\hline \multicolumn{13}{|l|}{ Total Government } \\
\hline \multirow[t]{2}{*}{ Employees } & & & 0.032 & & & -0.127 & & & -0.105 & & & -0.021 \\
\hline & & & [0.209] & & & {$[0.000]^{\star \star *}$} & & & {$[0.000]^{\star \star \star}$} & & & {$[0.341]$} \\
\hline \multirow[t]{2}{*}{ State Ownership } & -0.477 & -0.513 & -0.369 & -0.604 & -0.65 & -0.679 & -0.547 & -0.587 & -0.598 & -0.516 & -0.538 & -0.471 \\
\hline & {$[0.000]^{\star \star \star}$} & {$[0.000]^{\star \star \star}$} & {$[0.000]^{\star \star \star}$} & {$[0.000]^{\star \star \star}$} & {$[0.000]^{\star \star \star}$} & {$[0.000]^{\star \star \star}$} & {$[0.000]^{\star \star \star}$} & {$[0.000]^{\star \star \star}$} & {$[0.000]^{\star \star \star}$} & {$[0.000]^{\star \star \star}$} & {$[0.000]^{\star \star \star}$} & {$[0.000]^{\star \star \star}$} \\
\hline \multirow[t]{2}{*}{ Foreign Ownership } & -0.197 & -0.187 & -0.127 & 0.019 & 0.037 & -0.1 & -0.028 & -0.034 & -0.128 & -0.132 & -0.094 & -0.098 \\
\hline & {$[0.000]^{\star \star \star}$} & {$[0.001]^{\star \star \star}$} & {$[0.088]^{*}$} & [0.779] & [0.650] & {$[0.024]^{\star *}$} & [0.700] & [0.668] & {$[0.010]^{\star *}$} & {$[0.038]^{\star *}$} & [0.154] & [0.200] \\
\hline \multirow[t]{2}{*}{ Exporter } & 0.011 & 0.03 & 0.054 & 0.003 & 0.019 & 0.061 & 0.042 & 0.063 & 0.059 & -0.01 & -0.022 & 0.032 \\
\hline & [0.799] & [0.466] & [0.247] & [0.959] & [0.785] & [0.136] & [0.482] & [0.307] & {$[0.094]^{\star}$} & [0.825] & [0.659] & [0.518] \\
\hline \multirow[t]{2}{*}{ Firm Size } & -0.027 & -0.026 & -0.037 & -0.005 & -0.003 & -0.011 & 0.002 & 0.006 & -0.004 & -0.034 & -0.03 & -0.043 \\
\hline & {$[0.002]^{\star \star \star}$} & {$[0.005]^{\star \star \star}$} & {$[0.000]^{\star \star \star}$} & [0.626] & [0.819] & [0.118] & [0.758] & [0.449] & [0.419] & {$[0.000]^{\star \star \star}$} & {$[0.000]^{\star \star \star}$} & {$[0.000]^{\star \star \star}$} \\
\hline
\end{tabular}




\begin{tabular}{|c|c|c|c|c|c|c|c|c|c|c|c|c|}
\hline GDP per Capita & $\begin{array}{l}-0.393 \\
{[0.005]^{\star \star *}}\end{array}$ & $\begin{array}{l}-0.446 \\
{[0.015]^{\star \star}}\end{array}$ & $\begin{array}{l}-0.129 \\
{[0.738]}\end{array}$ & $\begin{array}{l}-0.174 \\
{[0.167]}\end{array}$ & $\begin{array}{l}-0.119 \\
{[0.332]}\end{array}$ & $\begin{array}{l}-0.036 \\
{[0.642]}\end{array}$ & $\begin{array}{l}-0.067 \\
{[0.320]}\end{array}$ & $\begin{array}{l}0.004 \\
{[0.957]}\end{array}$ & $\begin{array}{l}-0.045 \\
{[0.293]}\end{array}$ & $\begin{array}{l}-0.297 \\
{[0.003]^{\star \star \star}}\end{array}$ & $\begin{array}{l}-0.666 \\
{[0.000]^{\star \star \star}}\end{array}$ & $\begin{array}{l}-0.054 \\
{[0.782]}\end{array}$ \\
\hline Democratic & $\begin{array}{l}0.293 \\
{[0.123]}\end{array}$ & $\begin{array}{l}0.229 \\
{[0.168]}\end{array}$ & $\begin{array}{l}0.695 \\
{[0.003]^{\star \star \star}}\end{array}$ & $\begin{array}{l}-0.173 \\
{[0.344]}\end{array}$ & $\begin{array}{l}-0.731 \\
{[0.032]^{\star \star}}\end{array}$ & $\begin{array}{l}-0.186 \\
{[0.293]}\end{array}$ & $\begin{array}{l}-0.123 \\
{[0.326]}\end{array}$ & $\begin{array}{l}-0.455 \\
{[0.000]^{\star \star \star}}\end{array}$ & $\begin{array}{l}-0.023 \\
{[0.855]}\end{array}$ & $\begin{array}{l}0.071 \\
{[0.666]}\end{array}$ & $\begin{array}{l}0.178 \\
{[0.265]}\end{array}$ & $\begin{array}{l}0.236 \\
{[0.215]}\end{array}$ \\
\hline Fuel & $\begin{array}{l}-0.006 \\
{[0.003]^{\star \star *}}\end{array}$ & $\begin{array}{l}-0.009 \\
{[0.006]^{\star \star \star}}\end{array}$ & $\begin{array}{l}0.032 \\
{[0.000]^{\star \star \star}}\end{array}$ & $\begin{array}{l}0.002 \\
{[0.604]}\end{array}$ & $\begin{array}{l}-0.004 \\
{[0.329]}\end{array}$ & $\begin{array}{l}-0.007 \\
{[0.000]^{\star \star \star}}\end{array}$ & $\begin{array}{l}0.003 \\
{[0.289]}\end{array}$ & $\begin{array}{l}0.007 \\
{[0.000]^{\star \star *}}\end{array}$ & $\begin{array}{l}-0.025 \\
{[0.000]^{\star \star \star}}\end{array}$ & $\begin{array}{l}-0.006 \\
{[0.010]^{\star \star}}\end{array}$ & $\begin{array}{l}-0.011 \\
{[0.000]^{\star \star \star}}\end{array}$ & $\begin{array}{l}0.018 \\
{[0.003]^{\star \star \star}}\end{array}$ \\
\hline Imports & $\begin{array}{l}-0.001 \\
{[0.534]}\end{array}$ & $\begin{array}{l}-0.001 \\
{[0.629]}\end{array}$ & $\begin{array}{l}0.011 \\
{[0.003]^{\star \star \star}}\end{array}$ & $\begin{array}{l}-0.002 \\
{[0.626]}\end{array}$ & $\begin{array}{l}-0.002 \\
{[0.630]}\end{array}$ & $\begin{array}{l}-0.002 \\
{[0.465]}\end{array}$ & $\begin{array}{l}-0.001 \\
{[0.639]}\end{array}$ & $\begin{array}{l}-0.002 \\
{[0.567]}\end{array}$ & $\begin{array}{l}-0.017 \\
{[0.000]^{\star \star \star}}\end{array}$ & $\begin{array}{l}-0.004 \\
{[0.141]}\end{array}$ & $\begin{array}{l}-0.001 \\
{[0.807]}\end{array}$ & $\begin{array}{l}0.004 \\
{[0.359]}\end{array}$ \\
\hline Protestant & $\begin{array}{l}-0.772 \\
{[0.232]}\end{array}$ & $\begin{array}{l}-0.443 \\
{[0.362]}\end{array}$ & $\begin{array}{l}-1.034 \\
{[0.127]}\end{array}$ & $\begin{array}{l}-1.12 \\
{[0.020]^{\star \star}}\end{array}$ & $\begin{array}{l}-0.327 \\
{[0.643]}\end{array}$ & $\begin{array}{l}-0.544 \\
{[0.416]}\end{array}$ & $\begin{array}{l}-0.754 \\
{[0.171]}\end{array}$ & $\begin{array}{l}0.066 \\
{[0.911]}\end{array}$ & $\begin{array}{l}0.25 \\
{[0.482]}\end{array}$ & $\begin{array}{l}-0.286 \\
{[0.590]}\end{array}$ & $\begin{array}{l}-0.407 \\
{[0.430]}\end{array}$ & $\begin{array}{l}0.326 \\
{[0.591]}\end{array}$ \\
\hline British Colony & $\begin{array}{l}-0.014 \\
{[0.949]}\end{array}$ & $\begin{array}{l}-0.118 \\
{[0.635]}\end{array}$ & $\begin{array}{l}0.047 \\
{[0.818]}\end{array}$ & $\begin{array}{l}0.06 \\
{[0.734]}\end{array}$ & $\begin{array}{l}-0.289 \\
{[0.269]}\end{array}$ & $\begin{array}{l}-0.256 \\
{[0.083]^{\star}}\end{array}$ & $\begin{array}{l}0.048 \\
{[0.775]}\end{array}$ & $\begin{array}{l}-0.342 \\
{[0.017]^{\star \star}}\end{array}$ & $\begin{array}{l}-0.88 \\
{[0.000]^{\star \star \star}}\end{array}$ & $\begin{array}{l}0.161 \\
{[0.430]}\end{array}$ & $\begin{array}{l}0.261 \\
{[0.210]}\end{array}$ & $\begin{array}{l}0.303 \\
{[0.257]}\end{array}$ \\
\hline $\begin{array}{l}\text { Industry Dummies } \\
\text { Number of }\end{array}$ & yes & yes & yes & yes & yes & yes & yes & yes & yes & yes & yes & yes \\
\hline Countries & 29 & 26 & 18 & 38 & 28 & 17 & 33 & 26 & 17 & 34 & 28 & 18 \\
\hline Observations & 3099 & 2922 & 2123 & 3577 & 2898 & 2033 & 3233 & 2742 & 1937 & 3443 & 3078 & 2219 \\
\hline
\end{tabular}

Regressions run with ordered probit, based on standard maximum likelihood estimation, with heteroskedasticity-robust standard errors clustered by country. Detailed variable definitions and sources in Table 3. ***, **, and * indicate significance at the $1 \%, 5 \%$, and $10 \%$ levels, respectively.

P-values based on robust standard errors in parentheses. More developed countries are those with GDP per capita above the sample's median,

$\$ 5,995$. Less developed countries are those with GDP per capita below the median. 
Table 9: Probit Analysis: Decentralization and Corruption

\begin{tabular}{|c|c|c|c|c|c|c|c|c|}
\hline \multirow[b]{2}{*}{ Variable } & \multicolumn{8}{|c|}{ Model Specification } \\
\hline & $(1)$ & $(2)$ & $(3)$ & $(4)$ & $(5)$ & $(6)$ & $(7)$ & $(8)$ \\
\hline \multirow[t]{2}{*}{ Tiers } & 0.115 & 0.12 & 0.101 & 0.032 & 0.115 & 0.146 & 0.138 & 0.086 \\
\hline & {$[0.009]^{\star \star *}$} & {$[0.008]^{\star \star *}$} & {$[0.039]^{\star *}$} & {$[0.287]$} & {$[0.000]^{\star * *}$} & {$[0.000]^{\star \star \star}$} & {$[0.001]^{\star \star *}$} & {$[0.013]^{\star *}$} \\
\hline \multirow[t]{2}{*}{ Federal } & & -0.038 & & & & & & \\
\hline & & [0.513] & & & & & & \\
\hline \multirow[t]{2}{*}{ Federal X Bottom Unit Size } & & -0.007 & & & & & & \\
\hline & & {$[0.856]$} & & & & & & \\
\hline \multirow[t]{2}{*}{ Bottom Unit Size } & & -0.002 & -0.024 & & & & & -0.019 \\
\hline & & {$[0.054]^{\star}$} & {$[0.023]^{\star \star}$} & & & & & {$[0.364]$} \\
\hline \multirow[t]{2}{*}{ Autonomy } & & & -0.03 & & & & & \\
\hline & & & {$[0.628]$} & & & & & \\
\hline \multirow[t]{2}{*}{ Autonomy X Bottom Unit Size } & & & 0.03 & & & & & \\
\hline & & & {$[0.427]$} & & & & & \\
\hline \multirow[t]{2}{*}{ Bottom Tier Election } & & & & 0.045 & & & & \\
\hline & & & & {$[0.258]$} & & & & \\
\hline \multirow[t]{2}{*}{ Second Lowest Tier Election } & & & & -0.006 & & & & \\
\hline & & & & [0.881] & & & & \\
\hline \multirow[t]{2}{*}{ Subnational Revenues } & & & & & -0.008 & & & -0.012 \\
\hline & & & & & {$[0.054]^{*}$} & & & {$[0.002]^{\star \star \star}$} \\
\hline \multirow[t]{2}{*}{ Total Government Revenues } & & & & & -0.008 & & & -0.01 \\
\hline & & & & & {$[0.026]^{\star \star}$} & & & {$[0.012]^{\star \star}$} \\
\hline \multirow[t]{2}{*}{ Subnational Government Employment Share } & & & & & & 0.002 & & 0.003 \\
\hline & & & & & & {$[0.065]^{*}$} & & {$[0.023]^{\star *}$} \\
\hline \multirow[t]{2}{*}{ Total Government Employees } & & & & & & 0.007 & & -0.016 \\
\hline & & & & & & {$[0.225]$} & & {$[0.170]$} \\
\hline $\begin{array}{l}\text { Subnational Government Employment Ratio (\% } \\
\text { of Population) }\end{array}$ & & & & & & & $\begin{array}{l}0.049 \\
{[0.036]^{\star \star}}\end{array}$ & \\
\hline
\end{tabular}


Central Government Employment Ratio (\% of

Population)

\begin{tabular}{|c|c|c|c|c|c|c|c|}
\hline & & & & & & $\begin{array}{l}0.006 \\
{[0.834]}\end{array}$ & \\
\hline-0.168 & -0.167 & -0.17 & -0.165 & -0.162 & -0.196 & -0.201 & -0.186 \\
\hline$[0.000]^{\star \star *}$ & {$[0.000]^{\star \star *}$} & {$[0.000]^{\star \star \star}$} & {$[0.000]^{\star \star *}$} & {$[0.000]^{\star \star *}$} & {$[0.000]^{\star \star *}$} & {$[0.000]^{\star \star *}$} & {$[0.000]^{\star * *}$} \\
\hline-0.031 & -0.025 & -0.031 & -0.048 & -0.047 & -0.048 & -0.048 & -0.058 \\
\hline [0.133] & [0.229] & [0.175] & {$[0.017]^{\star *}$} & {$[0.008]^{\star \star *}$} & {$[0.006]^{\star \star *}$} & {$[0.006]^{\star \star *}$} & {$[0.002]^{\star \star \star}$} \\
\hline 0.021 & 0.017 & 0.02 & 0.008 & 0.017 & 0.008 & 0.006 & 0.022 \\
\hline [0.229] & [0.325] & [0.316] & [0.587] & [0.256] & [0.617] & [0.709] & [0.184] \\
\hline-0.001 & -0.002 & 0.000 & -0.005 & -0.006 & 0.000 & 0.000 & -0.002 \\
\hline [0.668] & [0.599] & [0.958] & {$[0.067]^{*}$} & {$[0.025]^{\star \star}$} & [0.901] & [0.941] & [0.340] \\
\hline-0.098 & -0.087 & -0.112 & -0.115 & -0.024 & -0.119 & -0.116 & -0.03 \\
\hline$[0.001]^{\star \star *}$ & {$[0.004]^{\star \star \star}$} & {$[0.001]^{\star \star \star}$} & {$[0.000]^{\star \star \star}$} & [0.531] & {$[0.000]^{\star * *}$} & {$[0.000]^{\star \star \star}$} & [0.494] \\
\hline-0.056 & -0.063 & -0.07 & -0.06 & -0.053 & -0.1 & -0.087 & 0.02 \\
\hline [0.339] & [0.325] & [0.280] & [0.342] & [0.470] & [0.126] & [0.221] & [0.786] \\
\hline 0.000 & 0.000 & 0.000 & 0.000 & -0.001 & -0.002 & -0.002 & -0.0003 \\
\hline [0.864] & [0.993] & [0.799] & [0.692] & [0.637] & [0.141] & [0.137] & [0.863] \\
\hline 0.000 & -0.001 & 0.000 & -0.002 & 0.000 & 0.000 & -0.001 & 0.001 \\
\hline [0.942] & [0.676] & [0.745] & {$[0.039]^{\star \star}$} & [0.909] & [0.807] & [0.696] & [0.586] \\
\hline-0.315 & -0.343 & -0.225 & -0.102 & -0.056 & -0.39 & -0.282 & 0.048 \\
\hline$[0.095]^{*}$ & {$[0.079]^{\star}$} & [0.271] & [0.561] & {$[0.746]$} & {$[0.047]^{\star \star}$} & [0.219] & [0.777] \\
\hline-0.003 & 0.013 & -0.008 & 0.092 & -0.045 & -0.062 & -0.059 & -0.101 \\
\hline [0.946] & [0.797] & [0.894] & [0.166] & [0.372] & [0.321] & [0.286] & [0.123] \\
\hline yes & yes & yes & yes & yes & yes & yes & yes \\
\hline 67 & 63 & 54 & 50 & 47 & 48 & 48 & 34 \\
\hline 6676 & 6527 & 5820 & 4775 & 5270 & 4998 & 4979 & 4101 \\
\hline
\end{tabular}

State Ownership

Foreign Ownership

Exporter

Firm Size

GDP per Capita

Democratic

Fuel

Imports

Protestant

British Colony

Industry Dummies

Number of Countries

$6676 \quad 6527$

5820

5270

4998

$4979 \quad 4101$

The regressions are run with probit, which is based on standard maximum likelihood estimation with heteroskedasticity-robust standard errors. Furthermore, we allow for clustering within countries to allow for possible correlation of errors in all the models. The coefficient estimates are transformed to represent the marginal effects evaluated at the means of the independent variables from the probit regressions. The marginal effect of a dummy variable is calculated as the discrete change in the expected value of the dependent variable as the dummy variable changes from 0 to 1. 
Table 10: Decentralization and Reported Frequency of Bribery for Particular Purposes

\begin{tabular}{|c|c|c|c|c|c|c|c|c|c|c|c|c|}
\hline \multirow[t]{2}{*}{ Variables } & \multicolumn{2}{|c|}{ Business Licenses } & \multicolumn{2}{|c|}{ Tax Collection } & \multicolumn{2}{|c|}{ Government Contract } & \multicolumn{2}{|c|}{ Public Utilities } & \multicolumn{2}{|l|}{ Customs } & \multicolumn{2}{|l|}{ Courts } \\
\hline & (1) & $(2)$ & (3) & (4) & (5) & (6) & (7) & (8) & (9) & (10) & $(11)$ & (12) \\
\hline \multirow[t]{2}{*}{ Tiers } & 0.188 & 0.152 & 0.22 & 0.148 & 0.148 & 0.089 & 0.128 & 0.059 & 0.161 & 0.057 & 0.025 & -0.05 \\
\hline & {$[0.004]^{\star \star *}$} & {$[0.001]^{\star \star \star}$} & {$[0.002]^{\star \star \star}$} & {$[0.038]^{\star *}$} & {$[0.055]^{\star}$} & {$[0.084]^{\star}$} & {$[0.068]^{\star}$} & [0.314] & {$[0.026]^{\star \star}$} & [0.411] & [0.823] & [0.748] \\
\hline \multirow[t]{2}{*}{ Federal } & -0.109 & & -0.069 & & -0.351 & & -0.303 & & -0.452 & & -0.105 & \\
\hline & [0.581] & & {$[0.726]$} & & {$[0.064]^{\star}$} & & {$[0.091]^{\star}$} & & {$[0.028]^{\star \star}$} & & [0.574] & \\
\hline \multirow[t]{2}{*}{$\begin{array}{l}\text { Federal } X \\
\text { Bottom Unit Size }\end{array}$} & -0.104 & & 0.028 & & -0.034 & & -0.128 & & 0.044 & & -0.032 & \\
\hline & [0.450] & & [0.828] & & [0.784] & & [0.361] & & [0.753] & & [0.811] & \\
\hline \multirow[t]{2}{*}{ Bottom Unit Size } & -0.003 & & -0.005 & & -0.004 & & -0.003 & & -0.007 & & -0.15 & \\
\hline & [0.358] & & [0.267] & & [0.132] & & [0.275] & & {$[0.021]^{\star \star}$} & & {$[0.037]^{\star \star}$} & \\
\hline $\begin{array}{l}\text { Subnational } \\
\text { Revenues }\end{array}$ & & -0.047 & & -0.016 & & -0.042 & & -0.033 & & -0.044 & & -0.034 \\
\hline \multirow[t]{2}{*}{$\begin{array}{l}\text { Total Government } \\
\text { Revenues }\end{array}$} & & -0.012 & & -0.025 & & -0.003 & & -0.007 & & -0.024 & & -0.012 \\
\hline & & {$[0.098]^{\star}$} & & {$[0.022]^{\star \star}$} & & [0.701] & & [0.385] & & {$[0.008]^{\star \star \star}$} & & [0.329] \\
\hline \multirow[t]{2}{*}{$\begin{array}{l}\text { Subnational Govt. } \\
\text { Employment Share }\end{array}$} & & 0.009 & & 0.006 & & -0.002 & & 0.001 & & -0.001 & & -0.004 \\
\hline & & {$[0.000]^{\star \star \star}$} & & {$[0.045]^{\star \star}$} & & [0.548] & & [0.564] & & [0.792] & & [0.234] \\
\hline \multirow[t]{2}{*}{$\begin{array}{l}\text { Total Government } \\
\text { Employees }\end{array}$} & & -0.102 & & -0.063 & & -0.07 & & -0.079 & & -0.1 & & -0.111 \\
\hline & & {$[0.000]^{\star \star *}$} & & {$[0.067]^{\star}$} & & {$[0.003]^{\star \star *}$} & & {$[0.000]^{\star \star \star}$} & & {$[0.000]^{\star \star *}$} & & {$[0.000]^{\star \star \star}$} \\
\hline \multirow[t]{2}{*}{ State Ownership } & -0.546 & -0.576 & -0.498 & -0.496 & -0.4 & -0.417 & -0.542 & -0.544 & -0.453 & -0.428 & -0.334 & -0.384 \\
\hline & {$[0.000]^{\star \star \star}$} & {$[0.000]^{\star \star \star}$} & {$[0.000]^{\star \star \star}$} & {$[0.000]^{\star \star \star}$} & {$[0.000]^{\star \star \star}$} & {$[0.000]^{\star \star \star}$} & {$[0.000]^{\star \star \star}$} & {$[0.000]^{\star \star \star}$} & {$[0.000]^{\star \star \star}$} & {$[0.000]^{\star \star \star}$} & {$[0.000]^{\star \star \star}$} & {$[0.000]^{\star \star \star}$} \\
\hline \multirow[t]{2}{*}{ Foreign Ownership } & 0.028 & -0.009 & -0.083 & -0.069 & -0.011 & -0.044 & 0.034 & -0.002 & 0.121 & 0.127 & 0.093 & -0.042 \\
\hline & {$[0.583]$} & {$[0.875]$} & [0.155] & {$[0.324]$} & [0.861] & [0.541] & [0.586] & [0.979] & {$[0.031]^{\star \star}$} & {$[0.080]^{*}$} & [0.195] & [0.689] \\
\hline Exporter & 0.094 & 0.14 & 0.095 & 0.12 & 0.261 & 0.283 & 0.002 & -0.012 & 0.408 & 0.402 & 0.089 & 0.168 \\
\hline
\end{tabular}




\begin{tabular}{|c|c|c|c|c|c|c|c|c|c|c|c|c|}
\hline Firm Size & $\begin{array}{l}-0.056 \\
{[0.000]^{\star \star \star}}\end{array}$ & $\begin{array}{l}-0.056 \\
{[0.000]^{\star \star \star}}\end{array}$ & $\begin{array}{l}-0.042 \\
{[0.000]^{\star \star \star}}\end{array}$ & $\begin{array}{l}-0.042 \\
{[0.001]^{\star \star \star}}\end{array}$ & $\begin{array}{l}-0.07 \\
{[0.000]^{\star \star \star}}\end{array}$ & $\begin{array}{l}-0.072 \\
{[0.000]^{\star \star \star}}\end{array}$ & $\begin{array}{l}-0.057 \\
{[0.000]^{\star \star \star}}\end{array}$ & $\begin{array}{l}-0.07 \\
{[0.000]^{\star \star \star}}\end{array}$ & $\begin{array}{l}-0.057 \\
{[0.000]^{\star \star \star}}\end{array}$ & $\begin{array}{l}-0.071 \\
{[0.000]^{\star \star \star}}\end{array}$ & $\begin{array}{l}-0.064 \\
{[0.000]^{\star \star \star}}\end{array}$ & $\begin{array}{l}-0.08 \\
{[0.000]^{\star \star \star}}\end{array}$ \\
\hline \multirow[t]{2}{*}{ GDP per Capita } & -0.293 & -0.247 & -0.467 & -0.292 & -0.227 & -0.07 & -0.416 & -0.306 & -0.386 & -0.068 & -0.231 & -0.173 \\
\hline & {$[0.000]^{\star \star \star}$} & {$[0.002]^{\star \star \star}$} & {$[0.000]^{\star \star \star}$} & {$[0.005]^{\star \star \star}$} & {$[0.023]^{\star *}$} & [0.439] & {$[0.000]^{\star \star \star}$} & {$[0.002]^{\star \star \star}$} & {$[0.000]^{\star \star *}$} & {$[0.480]$} & {$[0.010]^{\star *}$} & {$[0.098]^{\star}$} \\
\hline \multirow[t]{2}{*}{ Democratic } & 0.119 & 0.602 & 0.122 & 0.229 & -0.083 & -0.053 & 0.223 & 0.337 & 0.142 & 0.259 & -0.265 & 0.419 \\
\hline & [0.529] & {$[0.004]^{\star \star \star}$} & [0.553] & [0.320] & [0.683] & [0.768] & [0.158] & {$[0.147]$} & [0.469] & [0.320] & [0.375] & [0.372] \\
\hline \multirow[t]{2}{*}{ Fuel } & 0.001 & 0.003 & 0.001 & -0.001 & -0.002 & -0.008 & 0.002 & -0.002 & 0 & -0.005 & 0.003 & -0.004 \\
\hline & {$[0.773]$} & [0.322] & {$[0.752]$} & {$[0.737]$} & {$[0.450]$} & {$[0.040]^{\star \star}$} & {$[0.420]$} & [0.501] & [0.955] & {$[0.167]$} & [0.349] & {$[0.241]$} \\
\hline \multirow[t]{2}{*}{ Imports } & -0.005 & 0.001 & -0.005 & -0.002 & -0.009 & -0.007 & -0.007 & -0.004 & -0.007 & 0 & -0.008 & -0.008 \\
\hline & {$[0.082]^{*}$} & {$[0.760]$} & [0.107] & [0.665] & {$[0.007]^{\star \star \star}$} & [0.101] & {$[0.031]^{\star *}$} & [0.196] & {$[0.033]^{\star \star}$} & [0.989] & {$[0.035]^{\star \star}$} & {$[0.020]^{\star *}$} \\
\hline \multirow[t]{2}{*}{ Protestant } & -0.22 & 1.085 & -0.815 & -0.182 & 0.143 & 0.497 & -0.564 & 0.683 & -0.325 & 0.567 & 0.331 & 1.744 \\
\hline & [0.694] & {$[0.049]^{\star *}$} & {$[0.092]^{\star}$} & [0.668] & [0.802] & [0.363] & [0.253] & [0.289] & [0.521] & [0.453] & [0.679] & [0.141] \\
\hline \multirow[t]{2}{*}{ British Colony } & 0.105 & -0.322 & -0.015 & -0.182 & 0.444 & 0.511 & 0.674 & 0.598 & 0.335 & 0.409 & -0.344 & 0.107 \\
\hline & [0.593] & {$[0.125]$} & [0.940] & {$[0.404]$} & {$[0.052]^{\star}$} & {$[0.013]^{\star \star}$} & {$[0.000]^{\star \star *}$} & {$[0.047]^{\star *}$} & {$[0.081]^{\star}$} & {$[0.208]$} & {$[0.202]$} & [0.823] \\
\hline Industry Dummies & yes & yes & yes & yes & yes & yes & yes & yes & yes & yes & yes & yes \\
\hline Number of Countries & 61 & 34 & 61 & 34 & 61 & 34 & 61 & 34 & 61 & 34 & 49 & 27 \\
\hline Observations & 5809 & 3690 & 5780 & 3674 & 5450 & 3406 & 5889 & 3751 & 5391 & 3394 & 4874 & 3025 \\
\hline
\end{tabular}

Regressions run with ordered probit, based on standard maximum likelihood estimation, with heteroskedasticity-robust standard errors clustered by country. Detailed variable definitions and sources in Table $3 .{ }^{\star \star \star},{ }^{* \star}$, and * indicate significance at the $1 \%, 5 \%$, and $10 \%$ levels, respectively. P-values based on robust standard errors in parentheses. 